Document downloaded from:

http://hdl.handle.net/10251/62933

This paper must be cited as:

Cortes-Olmos, C.; Leiva-Brondo, M.; Rosello, J.; Raigón Jiménez, MD.; Cebolla Cornejo, J. (2014). The role of traditional varieties of tomato as sources of functional compounds. Journal of the Science of Food and Agriculture. 94(14):2888-2904. doi:10.1002/jsfa.6629.

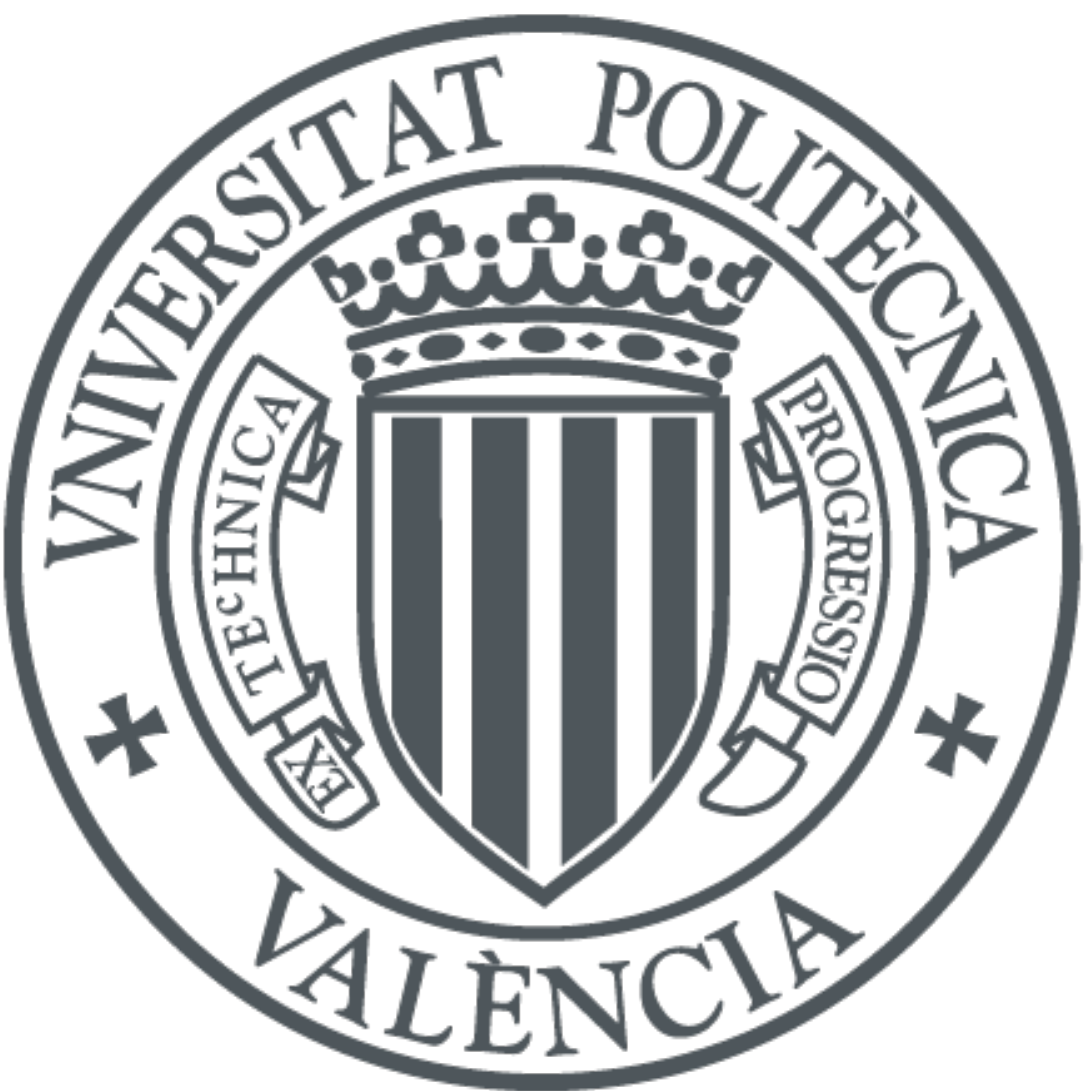

The final publication is available at http://dx.doi.org/10.1002/jsfa.6629

Copyright Wiley: 12 months

Additional Information 


\title{
THE ROLE OF TRADITIONAL VARIETIES OF TOMATO AS SOURCES OF NUTRIOTIONAL COMPOUNDS
}

Carles Cortés-Olmos ${ }^{\mathrm{a}+}$; Miguel Leiva-Brondo ${ }^{\mathrm{a}+}$; José Rosellób ${ }^{\text {j Jaime Cebolla-Cornejo }}{ }^{\mathrm{a}^{*}}$

anstituto Universitario de Conservación y Mejora de la Agrodiversidad Valenciana, COMAV. Universitat Politècnica de València. con.. de Vera, s.n. 46022, València, Spain.

${ }^{b}$ Estación Experimental Agraria de Carcaixent. Instituto Valenciano de Investigaciones Agriarias, IVIA. C/ Partida Barranquet, s.n. 46740, Carcaixent, Spain.

${ }^{+}$Equal contribution

${ }^{*}$ Corresponding author. Tel: +34-963879423. Fax: +34963879422. E-mail address: jaicecor@btc.upv.es

RUNNING TITLE

\begin{abstract}
BACKGROUND: Traditional varieties of tomato have developed their own niches in quality markets in some European markets associated with their excellent organoleptic quality.

RESULTS: A collection of 126 populations of 16 traditional varieties from the East of Spain (a secondary diversity center for tomato) have been evaluated during two years in order to determine their potential value also as sources of functional compounds, including ascorbic acid, lycopene and $\beta$-carotene. Population and population x year interaction significantly affect lycopene and ascorbic acid content, while year effect was also significant for $\beta$-carotene. Despite finding some global trends in certain varieties concerning their functional value, high levels of variation have been found in the intra-varietal level. Populations with high levels of the three levels have been found, with different
\end{abstract}


levels of intra-population and inter-year variation. Maximum mean contents for both years have reached $308 \mathrm{mg} \mathrm{kg}^{-1}$ of ascorbic acid, $130 \mathrm{mg} \mathrm{kg}^{-1}$ of lycopene and $30 \mathrm{mg} \mathrm{kg}^{-1}$ of $\beta$-carotene, though it is difficult to identify accessions with joint high values of the three compounds.

CONCLUSION: These results open the possibility to promote traditional materials as sources of functional compounds, thus strengthening their quality niches and consolidating their pricepremium. Additionally, these materials could also be used in breeding programs for quality.

\section{HIGHLIGHTS:}

- Traditional varieties of tomato have been evaluated for functional compounds.

- Some traditional populations of tomato show high contents in functional compounds.

- Some show limited degree of variability.

- They can supply quality markets with fruits with added functional value.

- They are a source of variation in breeding programs of commercial hybrid varieties.

\section{KEYWORDS:}

Lycopene, $\beta$-carotene, ascorbic acid, Solanum lycopersicum, quality, food composition

\section{INTRODUCTION}

Modern consumers are increasingly interested in their personal health and expect the food they eat to be healthy or capable of preventing illnesses (Granato et al., 2010). Among the functional foods that satisfy the requirements of these consumers, those including omega 3 fatty acids, plants sterols or probiotics, have experienced an upward trend in consumer interest (Jones and Jew, 2007). Accordingly, the dairy sector has experienced a boost in the development of this kind of products, though non-dairy matrices are also gaining prominence (Sun-Waterhouse, 2011). 
However, the niche market of functional food is not only restricted to processed products. There is also a trend to promote the characteristics of vegetable consumption in the diet. In this sense, dietary antioxidants and components of fruit and vegetable extracts are increasingly suggested to have the capacity to modulate the complex mechanisms involved in maintaining a healthy physiology and reducing early onset of age-dependent diseases (Auroma et al., 2012). It should also be considered that recent evidence suggests the ability of phytochemical components in whole foods is more effective in protectively supporting human health than isolated individual phytochemicals (Vattem et al., 2005). Accordingly, the development and commercialization of new varieties with increased levels of functional phytochemicals has become a new trend in the fruit and vegetable market and breeding industry.

In this context, tomato is included as one of the most studied active plant-based food (SunWaterhouse, 2011). In tomato marketing, as in other fruits and vegetables, a high content in active phytochemicals has gained importance, though it is not clear whether consumer interests in healthy products have conditioned the marketing of this kind of produces based on health functionality or vice versa (Goldman, 2011).

Among the different functional compounds present in tomato, vitamin $\mathrm{C}$ or ascorbic acid, carotenoids and flavonols have received most part of the attention. In the case of vitamin $\mathrm{C}$ the levels found in tomato compared with other species such as orange or broccoli are considerably low (Davey et al., 2000). But the high level of consumption of tomato, reaching 40-50 kg per capita and year in countries such as Spain, Italy or USA (source: FAO databases), makes this fruit one of the main sources for this vitamin. The carotenoid lycopene is in major part responsible for the red colour of ripe tomatoes, which represent the major source for this compound. It does not have provitamin A activity, but it has a physical quenching rate constant with singlet oxygen almost twice as high as that of $\beta$-carotene (Shi and Maguer, 2000). $\beta$-carotene is the second major carotenoid in tomato fruits, with concentrations around ten times lower than lycopene (Davies and Hobson, 1981). 
Several studies have determined an inverse relation between the intake in the diet of lycopene and $\beta$-carotene and the development of certain types of cancer (Ziegler, 1989; van Poppel and Goldbohm, 1995; Giovannucci, 1999) and a direct relation with a reduced incidence of heart disease (Palace et al., 1999; Rao, 2002). But in recent years some studies have questioned the relation between carotenoid or vitamin C intake and reduced cancer risk (Kavanaugh et al., 2007; Lin et al., 2009). Nonetheless, it should be considered the difficulty of proving that a specific component of a complex diet prevents the development of a disease. On the other hand, measurement errors in the dietary intake of fruit and vegetables may also attenuate these associations (Aune et al., 2012). In fact, recent publications again suggest moderate evidences between dietary vitamin $\mathrm{C}$ and $\beta$-carotene and the prevention of coronary heart disease (Mente et al., 2009). At the same time, new large population studies again confirm the existence of a certain relation between carotenoid intake and certain types of cancer, at least in some populations (e.g. Mignone et al., 2009).

Despite the absence of conclusive data for the role of tomato antioxidants in the prevention of a diseases, new varieties with increased levels of lycopene or other antioxidants are being developed (Ilahy et al., 2011). In this context, it should be considered that in successful marketing strategies, functional foods should deliver their health benefits above and beyond the standard perceived quality, including organoleptic quality, of the equivalent conventional food product. (Krystallis et al., 2008).

Consumer complains on the taste of modern commercial varieties (Bruhn et al., 1991) has fostered the development of niche markets for heirloom, local or traditional varieties. In fact, consumers appreciate the outstanding organoleptic quality of these materials and they are willing to pay a differential up to 4.70 times the price of commercial modern varieties (Cebolla-Cornejo et al., 2007). These varieties have shown high levels of variation in agro-morphological, genetic (Casals et al., 2011) and organoleptic levels (Cebolla-Cornejo, 2011), but little is known on the variation in the concentrations of functional compounds, such as the antioxidants previously described. The 
objective of this study is to provide a consistent evaluation of the composition in key antioxidant compounds in traditional varieties of tomato. In this case, Spanish traditional varieties have been selected as a model study to examine their diversity in an inter- and intra-variety scale using a large collection of populations. These findings may be relevant both in the promotion of these materials targeted to quality niche markets combining excellent taste with an added functional value, and in the use of these materials as sources of variation in breeding programs.

\section{MATERIALS AND METHODS}

\section{Plant Material}

A total of 126 populations belonging to 16 different Spanish traditional varieties of tomato (Solanum lycopersicum L.), were studied during two consecutive years, 2009 and 2010 (Table 1). Most of them, including 115 populations, were provided by the Instituto Universitario de Conservación y Mejora de la Agrodiversidad Valenciana (COMAV, València, Spain) germplasm bank, eight populations were provided by Estación Experimental Agraria de Carcaixent, (EEAC, belonging to the Instituto Valenciano de Investigaciones Agrarias, IVIA, Carcaixent, Spain) and three populations were obtained in local nurseries. A different number of populations were studied per variety, considering the different interest of local markets and the amount of diversity available in the germplasm banks: one population belonged to the variety 'Amarillo', one to 'Centenares, six to 'Cuarenteno', ten to 'De Colgar', four to 'De la Pera', three to 'De Pera', one to 'Elchero', two to 'Flor de Baladre', four to 'Gordo Rojo', 28 to 'Muchamiel', one to 'Negre', eight to 'Pimiento', two to 'Redondo Rojo', 12 to 'Rosa', one to 'Tres Cantos' and 42 to 'Valenciano'. These varieties represent representing a wide diversity of fruit colours and shapes (Table 1).

Furthermore, four commercial $\mathrm{F}_{1}$ hybrids, genetically uniform, were kindly provided by Rijk Zwaan Iberica S.A (Almería, Spain) and were included and used as a control. The variety 'Razymo RZ' 
presents round, red, medium sized tomatoes, 'Gransol RZ' presents slightly flattened, large sized fruits and 'Piccota RZ' presents round, small sized Cherry type fruits and 'Mariscal RZ' presents flattened, medium to large sized fruits.

\section{Experimental Design and Crop Conduction}

The seedbeds were sown in April and were transplanted to field in May in 2009 and 2010. The trial was carried out in a $5800 \mathrm{~m}^{2}$ field located in Carcaixent $\left(+39^{\circ} 6^{\prime} 37.13^{\prime \prime},-0^{\circ} 26^{\prime} 45.05^{\prime \prime}\right.$, València, Spain), surrounded by orange trees. There were no other vegetable crops grown in the proximities. The field was previously cleaned and fertilized with $36,000 \mathrm{~kg}$ of sheep manure and $200 \mathrm{~kg}$ of potassium sulphate.

A randomized complete block design was used with two blocks, and 2 replicates of 10 plants per population and block. A spacing of $1.2 \mathrm{~m} \mathrm{x} 0.4 \mathrm{~m}\left(2.1\right.$ plants $\left.\mathrm{m}^{-2}\right)$ was applied. The crop was managed using the traditional practices for tomato cultivation in the area, including staking, pruning and drip fertirrigation. In order to control Tuta absoluta Meyrick population, pesticide treatments were performed when insect counts suggested the convenience.

\section{Sampling}

Healthy and uniformly ripe fruits were harvested at the mature-red stage from second to third truss. Samples were composed of a mix of representative fruits of each of the 10 plants in the replicate. In order to provide a biological mean, equivalent longitudinal portions for each fruit were blended using a blender (KRUPS KB720, Groupe Seb Iberica, Barcelona, Spain), and subsequently homogenized through a laboratory homogenizer (Diax 900, Heildolph, Germany), which was able to disrupt tissue to particle sizes $<0.4 \mathrm{~mm}$. Samples were quickly cryopreserved using liquid nitrogen and were kept frozen at $-80^{\circ} \mathrm{C}$ until analysis.

\section{Characterization}


All the populations were morphologically characterized to study the correlation between chemical composition and morphological traits. The following descriptors were evaluated: Fruit height (mm), fruit width (mm), fruit width to fruit height ratio, fruit core width ( $\mathrm{mm})$, fruit core width to fruit width ratio, pericarp thickness $(\mathrm{mm})$, pericarp thickness to fruit width ratio, number of locules and fruit colour. Fruits colour was analysed using Hunter coordinates through a digital colorimeter (CR 300, Minolta, Japan). Results of each sample were based on the average of three determinations taken on ten representative fruits. The results were reported $a s, a, b$ and $a / b$ rate.

\section{L-ascorbic acid quantification}

Ascorbic acid was quantified by capillary zone electrophoresis using a P/ACE System MDQ (Beckman Instruments, Fullerton, CA, USA) using the method described by Galiana-Balaguer et al. (2001). Two grams of sample were thawed in the dark at $4^{\circ} \mathrm{C}$ and centrifuged at $3500 \mathrm{rpm}$ during 5 minutes. The supernatant was diluted in $2 \%(\mathrm{w}: \mathrm{v})$ metaphosphoric to avoid oxidation, and potassium hydrogen phtalate was added as internal standard. Samples were filtered, prior to injection, using a $0.22 \mu \mathrm{m}$ membrane filter (Millipore, Ultrafree-MC, MA, USA).

Uncoated fused-silica capillaries with a $31.2 \mathrm{~cm}$ total length, $21 \mathrm{~cm}$ effective length, $363 \mu \mathrm{m}$ e.d. and $50 \mu \mathrm{m}$ i.d. were used (Polymicro Technologies, Phoenix, AZ, USA). Hydrodynamic injection of samples was carried out at 0.5 psi for 5 seconds. Separation was performed at $-15 \mathrm{kV}$ and $25^{\circ} \mathrm{C}$. The detection wavelength was $254 \mathrm{~nm}$. Two analytical replicates per sample were made. Results were expressed as $\mathrm{mg} \mathrm{kg}^{-1}$ fresh weight (fw).

\section{Carotenoid quantification}

Samples were thawed in the dark at $4^{\circ} \mathrm{C}$ and $100 \mathrm{mg}$ of the homogenate were extracted with $7 \mathrm{ml}$ of a $4: 3 \mathrm{v} / \mathrm{v}$, ethanol/hexane solution at $4^{\circ} \mathrm{C}$, during 1 hour at $200 \mathrm{rpm}$ using an horizontal shaker (Platform Rocker STR6, Viví, Stuart). Hexane was complemented with $0.05 \%$ butylated hydroxytoluene, (BHT). Hexane supernatant was separated and concentrated using a SpeedVac 
(Termo, RVT 4104) to complete dryness, and then re-suspended in $500 \mu 1$ of hexane. Sudan I was added as internal standard and the processed sample was then filtered using a hydrophobic filter of $0.20 \mu \mathrm{m}$ (Millex-FG, Phobic PTFE). During all the process samples were protected from light.

The quantification of the carotenoids lycopene and $\beta$-carotene was carried out by reverse phase high performance liquid chromatography (HPLC) using the method reported by García-Plazaola and Becerril (1999) with slight modifications. Analyses were performed on a 1200 series chromatographer (Agilent Technologies, Santa Clara, US) with G1322A vacuum degasser, G1312A quaternary pump, G1329A standard autosampler, G1316 thermostated column compartment and G1315b diode array detector. A reserved phase Tracer Spherisorb ODS-1 (250 x $4.6 \mathrm{~mm}$ i.d., $5 \mu \mathrm{m}$ particle size $)$ column protected by a guard column $(20$ x $3.9 \mathrm{~mm}$ i.d., $4 \mu \mathrm{m}$ particle size $)$ was used. Mobile phase consisted of two components: solvent A with 84:9:7 v/v/v, acetonitrile/methanol/water and solvent B with $68: 32 \mathrm{v} / \mathrm{v}$, methanol/ethyl acetate. The injection volume was $40 \mu 1$. Sample was then eluted using a lineal gradient from $100 \%$ of solvent A to $100 \%$ of solvent B during 12 minutes, followed by an isocratic elution of $100 \%$ of solvent B during 7 minutes. Then, a lineal gradient was established from $100 \%$ of solvent B to $100 \%$ of solvent A during 1 minute. Finally, an isocratic elution of $100 \%$ of solvent A during 6 minutes was performed to allow the column to re-equilibrate.

The integrations of $\beta$-carotene and lycopene were performed at $445 \mathrm{~nm}$ and $470 \mathrm{~nm}$ respectively. Two analytical replicates per sample were made. The results were reported as $\mathrm{mg} \mathrm{kg}^{-1} \mathrm{fw}$.

\section{Statistical analysis}

Correlations and bilateral signification between variables were calculated. Population and block effects were analysed with an ANOVA. Variety effect was not estimated due to the unbalanced design and the low number of populations in some varieties. Statistical analyses were performed using the statistical package SPSS v.12 (SPSS Inc., Chicago, IL, USA). Bartlett's test was used to check significant differences in the variances of the populations evaluated in each year. 
For the analysis of variability, intra-population coefficient of variation (IPCV) was calculated for each year, as well as the mean of IPCV for both years. Inter-year coefficient of variation (IYCV) was calculated with the means of the contents for each year.

\section{RESULTS}

The growing cycle in 2009 was almost 15 days shorter in 2009 than in 2010. Despite this difference in the growing speed, environmental conditions were not so much different (figure 1). Photosynthetically active radiation (PAR) was similar in both years (figure 1), though cumulative PAR in the first third of the cycle was higher in 2009. Final cumulative PAR per day was also slightly higher in $2009\left(1838 \mu \mathrm{mol} \mathrm{m} \mathrm{m}^{-2} \mathrm{~s}^{-1}\right.$ vs. $\left.1807 \mu \mathrm{mol} \mathrm{m} \mathrm{m}^{-2} \mathrm{~s}^{-1}\right)$.

Temperatures, especially maximum ones were slightly higher in most part of the growing cycle during 2009 than in 2010 , with mean maximum temperature for 2009 of $30.1^{\circ} \mathrm{C}$ and $29.5^{\circ} \mathrm{C}$ for 2010 . In both cycles, maximum temperatures higher than $32^{\circ} \mathrm{C}$ were registered at the end of the cycle for both years (32 days for 2009 and 45 days for 2010). The difference would be that in 2009 higher values were obtained during those days, and in fact mean maximum temperature for those days was $35.7^{\circ} \mathrm{C}$ for 2009 and $34.6^{\circ} \mathrm{C}$ for 2010 .

Lycopene accumulation was strongly influenced by the population factor $\left(\mathrm{p}<10^{-6}\right)$ and the interaction between population and year of cultivation $(\mathrm{p}=0.0005)$, while the year of cultivation (environment) was not significant $(\mathrm{p}=0.85)$. On the contrary, in the case of $\beta$-carotene population $\left(\mathrm{p}<10^{-6}\right)$, year of cultivation $(p=0.00003)$ and their interaction were highly significant $\left(p<10^{-6}\right)$. In this case lower contents of $\beta$-carotene were obtained with the environmental conditions of year 2010 . In the case of ascorbic acid, the year effect was not significant $(\mathrm{p}=0.094)$, as the environmental effect affected differently each population, thus a strong year $\mathrm{x}$ population interaction was detected $(\mathrm{p}=0.00003)$. Following the trend for the other compounds, population effect was highly significant $\left(\mathrm{p}<10^{-6}\right)$. The 
variety effect was not considered in the model, as different numbers of populations were included for each variety, and it was not the purpose of this work to analyse this factor, but rather to detect interesting populations from the functional point of view, no matter from which variety they belonged to.

Moderate significant correlations were obtained between lycopene content and fruit external colour parameters (table 2). For this compound, low significant correlations were found with fruit height (positive) and fruit width and fruit width to fruit height ratio (negative). For $\beta$-carotene only low significant negative correlations were found $(<0.4)$ with colour, size and shape parameters and number of locules. In this case the only positive correlation was found with the pericarp thickness to fruit width ratio. In the case of ascorbic acid, only low significant negative correlations were found with colour and size parameters and number of locules. No significant correlation over 0.2 was detected among the contents of the different compounds.

The levels of variation detected in the accumulation of functional compounds were population dependant. In fact, Bartlett's test confirmed that the variances were different in $2009\left(\mathrm{p}<10^{-6}\right)$ and in $2010(\mathrm{p}=0.0003)$ for lycopene, $\beta$-carotene $\left(\mathrm{p}<10^{-6}\right.$ both years) and ascorbic acid $\left(\mathrm{p}<10^{-6}\right.$ both years). Consequently, variability was also analysed in intra-population and inter-year levels. Ascorbic acid accumulation registered the higher level of intra-population variation, IPCV (table 3), with mean values considering all populations of 0.40 followed by lycopene $(0.33)$ and $\beta$-carotene $(0.17)$. A similar pattern was observed for the variation between different years, but with limited differences in the variation of the carotenoids (table 3). In this case, the mean inter-year coefficient of variation, IYCV, was respectively $0.35,0.24$ and 0.28 . The level of variation was also affected by environmental conditions. For example, in 2010 the intra-population coefficients of variation for ascorbic acid were lower.

A high level of intra-varietal variation was detected for the three compounds, though for ascorbic acid it was considerably lower (table 4). Among the different varieties, 'De colgar' and 'Rosa' 
showed the higher range of variation in their populations. These varieties also showed high levels of mean IPCV. The high level of variation made difficult to assign a certain functional profile for each variety. Nevertheless general trends could be found. For example, the variety 'Amarillo' showed low levels of carotenoids, as expected due to their yellow external colour. Variety 'Centenares' showed in general high values for the three compounds, while 'De pera' and 'Pimiento' stood out for lyconene accumulation and 'De colgar' and 'Redondo rojo' for $\beta$-carotene.

\section{Ascorbic acid}

In each variety, a wide range of population was found and several populations were identified with outstanding values for each compound. Ten populations showed ascorbic acid contents higher than $200 \mathrm{mg} \mathrm{kg}-1$, and one them higher than $300 \mathrm{mg} \mathrm{kg-1} \mathrm{(table} \mathrm{3).} \mathrm{In} \mathrm{several} \mathrm{cases} \mathrm{though,} \mathrm{inter-year}$ coefficient of variation was considerably high. Therefore, these populations could be considered unstable. Nevertheless, population CDP00142 from 'Valenciano' with $308.1 \mathrm{mg} \mathrm{kg-1and} \mathrm{IYCV} \mathrm{of}$ 0.44, population CDP01040 from 'De Colgar' with $262.7 \mathrm{mg} \mathrm{kg-1}$ mean content and IYCV of 0.16 , population CDP05973 from 'Cuarenteno' with $216.1 \mathrm{mg} \mathrm{kg}^{-1}$ mean content and IYCV of $0.10 \mathrm{cv}$ and population CDP05079 from 'De Colgar' with $253.6 \mathrm{mg} \mathrm{kg}^{-1}$ mean content and IYCV of 0.02 could be interesting from the point of view of ascorbic acid accumulation.

\section{Carotenoids}

In the case of lycopene eight populations showed contents higher than $100 \mathrm{mg} \mathrm{kg}^{-1}$ (table 3 ). The higher mean contents were detected in the populations CDP04303 from 'Rosa' with $151.9 \mathrm{mg} \mathrm{kg}^{-1}$ and CDP06083 from 'Pimiento' with $132.2 \mathrm{mg} \mathrm{kg}^{-1}$. In the case of population CDP04303 the IYCV was considerably high (0.72) and showed high differences in the mean content for each year, but populations CDP06083, or CDP00929 from 'De pera', with mean content of $123.59 \mathrm{mg} \mathrm{kg}^{-1}$, showed medium to high contents with low IYCV (0.21 and 0.13 respectively). 
Regarding $\beta$-carotene accumulation, 23 populations of traditional varieties of tomato showed $\beta$ carotene mean contents higher than $20 \mathrm{mg} \mathrm{kg}^{-1}$ and two of them, populations CDP07064 from 'Redondo Rojo' and CDP03774 from 'De colgar' outreached 30 mg kg-1, with medium IYCV (0.31 and 0.32 respectively).

As shown above, it was possible to identify materials with moderate to high contents and low IPCV and IYCV indicating a high degree of stability. It was much more difficult to identify materials with outstanding values for several compounds. In fact, no significant important correlations were found between ascorbic acid and carotenoids nor between lycopene and $\beta$-carotene (table 2). Nonetheless, population CDP05729 and CDP00450 belonging to the variety 'Valenciano' combined moderate to high levels of $\beta$-carotene and lycopene.

\section{DISCUSSION}

Among the functional compounds evaluated, ascorbic acid showed the higher degree of variation at the intra-population and inter-year scales. Intra-population level of variation would be mainly related to genotype and micro-environmental effects, while inter-year variation would be mainly related to macro-environmental effects. The genotype component of intra-population variation is explained by the complex genetic structure of traditional varieties that are usually configured as population varieties, formed by a mixed of different genotypes that may explain high variability in an intra-year intra-population basis. Among the environmental components, micro-environmental effects would be explained by small differences in temperature, soil, fertirrigation etc., while macro-environmental effects would be mainly related with the different climatic conditions of both years of cultivation.

It is difficult to determine which part of intra-population variation is due to genetic differences between the individuals of each population or to micro-environment. Nevertheless, the fact that the F1 hybrid controls, which are genetically uniform, showed similar values of intra-population 
coefficients of variation compared to traditional populations seems to indicate that the main factor explaining this level of variation would be micro-environmental differences in the growing conditions of each plant. It should be considered that the different levels of intra-population variation imply a lack of homoscedasticity. Therefore, despite the robustness of the ANOVA analysis, the results obtained should be considered only as indicative.

Inter-year variation might be explained by the different climatic conditions. These differences would not only affect mean content, but also might buffer the level of variation, as it happened with ascorbic acid in 2010 when the intra-populations coefficients of variation were lower. But, the environmental effect would not be explained by generalized trends, as its effect would be mainly explained by a strong population $\mathrm{x}$ year interaction. In fact, previous studies decomposing phenotypic variances have shown that differences in ascorbic acid in promising materials are mostly due to a high GxE interaction rather than to environmental effect (Leiva-Brondo et al., 2012). This interaction might explain the extraordinary levels in several traditional populations during the year 2010, with contents higher than $300 \mathrm{mg} \mathrm{kg}^{-1}$ in three populations, as compared to the levels obtained in 2009 , when this content was not reached by any population.

In the case of ascorbic acid, Dumas (2003) reported higher effects of solar radiation than temperature. In our case, the PAR registered in the middle part of the growing cycle was similar for those years, while 2009 registered slightly higher maximum and minimum temperatures. Considering that during this period maximum temperatures exceeded $30^{\circ} \mathrm{C}$, these conditions could have led to stressing situation that might have led to a consumption of ascorbic acid, thus explaining lower levels obtained in several populations in this year. Nevertheless, it should be considered that other studies, even though recognizing a probable influence of radiation and temperature in ascorbic accumulation, did not find clear correlations with climatic parameters (Raffo et al., 2006). In the same sense, Hamner et al. (1945) found that environmental effects were higher than genotypic effects, but found it difficult to ascribe the differences to a specific cause. 
As the variation in carotenoid contents is concerned, the lower levels of intra-year variation in $\beta$ carotene content than those for ascorbic acid and lycopene have been already observed in previous studies where different materials have been screened as sources of variation in breeding programs for these compounds (Roselló et al., 2011).

Regarding the environmental effect on carotenoids, the differences in the significance of the environmental factor between lycopene and $\beta$-carotene could be related to the environmental regulation of the biosynthetic pathway. As commented for ascorbic acid, maximum temperatures were higher in the middle part of the growing cycle during 2009 , and higher than $30^{\circ} \mathrm{C}$. Under these conditions, lycopene biosynthesis is restrained, while its conversion to $\beta$-carotene continues, and this might explain higher levels of this compound in those years with higher maximum temperatures.

The high degree of variation in intra-population and inter-year scale indicates that the use of high contents in functional compounds as a marketing strategy in tomato should be carefully addressed. Multi-environmental assays are essential to clearly identify the minimum levels of accumulation; otherwise consumer might be deceived if the materials are cultivated in worse environmental conditions. These assays would also be valuable to identify which growing conditions promote the accumulation of each of the materials considered, due to the high genotype $\mathrm{x}$ environment interaction.

\section{Ascorbic acid}

But before that, it should be considered if there is really an opportunity in the traditional varieties of tomato in the market of functional foods. The mean ascorbic content in most of the populations analysed represented, in general, conventional values of tomato cultivars. Gould (1992) established $200 \mathrm{mg} \mathrm{kg}^{-1}$ as the normal content in commercial varieties, while George et al. (2004) found in a more recent study a range between 92 and $324 \mathrm{mg} \mathrm{kg}^{-1}$ in tomato pulp, though the highest values corresponded to cherry tomatoes. And in this case, as ascorbic acid can be found at higher 
concentrations in the jelly and skin than in the pericarp, small fruited varieties tend to have higher contents than standard varieties (Stevens et al., 2007). In our case, the population CDP08734 of the variety 'Centenares' (cherry type) and the cherry control 'Piccota RZ' gave high contents of ascorbic acid, but not the highest ones. Nevertheless, low negative correlations were found with size parameters and number of locules. As it has been indicated, ascorbic acid content is higher in the locular matrix. As usually a higher number of locules represents lower size of locules, this would explain the negative correlation found between this parameter and ascorbic content.

Apart from that small fruited population, our results here also show that it is possible to identify materials such as the medium sized 'Valenciano' population CDP00142 with contents as high as $308.1 \mathrm{mg} \mathrm{kg}^{-1}$. Bhatt et al. (2001) identified heterotic effects studying diallel crosses with maximum ascorbic contents in the $\mathrm{F}_{1}$ populations of $341.3 \mathrm{mg} \mathrm{kg}^{-1}$, a content difficult to find in standard varieties. Consequently, the contents found in the collection of traditional populations would not only be interesting to promote the consumption of these materials, but make these populations useful in breeding programs.

But, would really these materials be interesting in breeding programs? In this context, wild species, with up to 5 times the content of ascorbic acid of commercial varieties, have been used for this purpose, and some of the QTL controlling the underlying genetic control have been identified (Stevens et al., 2007). In these programs the final content is not as high as expected considering the donor parent. For example in studies analysing the introgression from the wild species Solanum pennellii Correl, the wild parent may accumulate up to $710 \mathrm{mg} \mathrm{kg}^{-1}$, but the when it is crossed with the cultivated species, the contents in introgression lines of tomato range up to $273.3 \mathrm{mg} \mathrm{kg}^{-1} \mathrm{fresh}$ weight (Stevens et al., 2007). Nevertheless, it is true that ascorbic acid is highly influenced by the environment (Toor et al., 2006), and probably it would be possible to obtain higher amounts of ascorbic acid in breeding lines derived from high ascorbic wild species. 
But in any case, our results show again that it is possible to identify high contents in traditional varieties that equal or even exceed the contents of elite breeding lines bred with this purpose, avoiding the negative side effects of the use of wild species. In this sense, it should be remembered the case of "Double Rich" cultivars. They were developed through interespecific crosses between cultivated tomato and Solanum peruvianum L. accessions and their ascorbic acid contents (500 $\mathrm{mg}$ $\mathrm{kg}^{-1}$ ) doubled the normal contents, however, their small fruit size and their poor production limited their use on a commercial level (Stevens and Rick, 1986). Moreover, "Double Rich" cultivars showed lower contents $\left(318 \mathrm{mg} \mathrm{kg}^{-1}\right.$ ) in other trials (Watada et al., 1976), in a range similar to that of population CDP00142 in this study.

The high levels of ascorbic acid found in some populations would not only result in improved nutritive or functional value of plants, but also may have a side effect on the plant response against different stresses. In fact, ascorbic acid biosynthesis and recycling have been related with plant heath and development and in particular to abiotic stress tolerance (Gallie, 2013).

\section{Carotenoids}

Regarding the results for lycopene accumulation, the amounts registered in some populations of traditional varieties in this work demonstrate that there is an alternative for the improvement of its accumulation besides the use of wild species. Two populations displayed lycopene contents higher than $130 \mathrm{mg} \mathrm{kg}^{-1}$ which can be placed at the lower range of variation of "high pigment" cultivars, especially considering the big size of these materials. In this sense, the distribution of major carotenoids in the ripe fruit is irregular, with more than 2-fold amounts of lycopene in the pericarp than in the locules and 4-fold higher amounts of $\beta$-carotene in the locules than in the pericarp (Davies and Hobson, 1981). That would mean that those populations with smaller size would have more probabilities to show high lycopene contents, as the relation surface to volume would be higher. Despite this relation in our study the commercial cherry control 'Piccota RZ' showed a standard lycopene content while 'Centenares' had a moderately high content (table 3). 
It should also be considered that the values obtained here could be surpassed in other environments. Temperatures over $32^{\circ} \mathrm{C}$ inhibit lycopene biosynthesis (Dumas et al., 2003) and during the last part of the cycle of the two years, maximum temperatures overreached that limit. Therefore, lycopene accumulation in the materials evaluated should not be at their maximum potential.

Holden et al. (1999) reported that the standard lycopene content in red ripe raw tomatoes in the United States would be $30.25 \mathrm{mg} \mathrm{kg}^{-1}$. Considering environmental and genotypic effects, it is reasonable that different studies in other parts of the world could be higher. In fact, MartinezValverde (2002) analysing different varieties and growing cycles in Spain found lycopene contents in winter growing cycle up to $64.98 \mathrm{mg} \mathrm{kg}^{-1}$. These standard values have been considerably improved in "high pigment" tomato varieties, with contents up to $254 \mathrm{mg} \mathrm{kg}^{-1}$, though strong environmental effects led to a variation of up to 25 in different growing seasons (Ilahy et al., 2011). These varieties carry any of the "high pigment" mutations $(h p-1, h p 2 \ldots)$ that result in increased carotenoid content, especially lycopene. These mutations are related with light signal transduction machinery and result in increased light response and a consequent increase in the levels of carotenoids and other compounds including flavonoids and ascorbic acid (Bino et al., 2005). These genes and modifiers have been used in breeding programs targeted to the development of new functional varieties (Levin et al., 2004). Nonetheless, these mutations have secondary side effects resulting in worse agronomic performance and consequently those genes, such as $\mathrm{og}^{c}$, involved in single steps of the biosynthetic pathway have retained interest in breeding programs (Sacks and Francis, 2001).

In the case of $\beta$-carotene, the content in standard varieties rounds $3.93 \mathrm{mg} \mathrm{kg}^{-1}$ (Holden et al., 1999). Several high $\beta$-carotene varieties have been developed using wild species as donor parents. As an example, the cultivar "CaroRed" offered contents of $\beta$-carotene up to $44.2 \mathrm{mg} \mathrm{kg}^{-1}$ (Tomes and Queackenbush, 1958). Usually these materials show orange colour, as the increase in the content of $\beta$-carotene is due to the cyclisation of lycopene, and therefore at its expense. Despite offering high levels of pro-vitamin A, consumers have not shown a considerable interest in these materials due to 
the orange external colour, and it is preferred to combine in the same materials high $\beta$-carotene with normal to high content in lycopene, resulting in red coloured tomatoes. Following this target, it has been possible to identify wild cherry accessions with similar $\beta$-carotene contents to those above mentioned with normal lycopene contents (Adalid et al., 2012). In this work, it has been possible to identify several populations of traditional varieties of tomato with $\beta$-carotene mean contents higher than $20 \mathrm{mg} \mathrm{kg}^{-1}$, and some higher than $30 \mathrm{mg} \mathrm{kg}^{-1}$. Consequently, the levels obtained can be compared with those found in the best high pigment tomato cultivars that range up to $20 \mathrm{mg} \mathrm{kg}^{-1}$ fresh weight in open field conditions (Lenucci et al., 2006).

\section{CONCLUSION}

The variation present in traditional populations of tomato enables the identification of materials with moderate to high contents in functional compounds and limited degree of variability. These materials could be then targeted to supply quality markets demanding not only produces with high organoleptic characteristics but also an added functional value. For this purpose it would be convenient to develop intra-varietal complementary crosses in order to develop new populations with high levels of joint accumulations of the three compounds. This strategy would be very valuable to explore the possibilities of obtaining a price premium as a result of the added functional value. In other functional food markets these price premia has been ranged between 30\%-50\% (Menrad, 2003). And this difference would be useful to compensate the usually lower yields of traditional varieties. Thus, it will contribute to offer an in situ conservation promoting the recovery of these materials by farmer. In addition, Spanish growing condition seem not only to contribute to high levels of carotenoids in tomato, but also promote their bioaccessibility (Aherne et al., 2009), thus strengthening the added value of these materials. Additionally, these genetic resources could also be used as sources of variation in breeding programs of new commercial hybrid varieties. Considering that the high levels detected are already present in medium-large sized fruits and that the contents detected are even 
higher than previously found sources of variation in small fruited accessions (Adalid et al., 2010), these materials seem to be promising alternatives for this purpose.

\section{Acknowledgements}

The funds for development of this research were provided by Fundación de la Comunidad Valenciana para la Investigación Agroalimentaria (AGROALIMED)

\section{References}

1. Adalid AM, Roselló S and Nuez F, Evaluation and selection of tomato accessions (Solanum section Lycopersicon) for content of lycopene, $\beta$-carotene and ascorbic acid. J Food Compos Anal 23:613-618 (2010).

2. Adalid A, Roselló S, Valcárcel M and Nuez F, Analysis of the genetic control of $\beta$-carotene and 1-ascorbic acid accumulation in an orange-brownish wild cherry tomato accession. Euphytica 184:251-263 (2012).

3. Aherne SA, Jiwan MA, Daly T and O'Brien NM, Geographical Location has Greater Impact on Carotenoid Content and Bioaccessibility from Tomatoes than Variety. Plant Foods Hum Nutr 64:250-256 (2009).

4. Aruoma OI, Coles LS, Landes B and Repine JE, Functional benefits of ergothioneine and fruit- and vegetable-derived nutraceuticals: Overview of the supplemental issue contents. Prev Med 54, Supplement:S4-S8 (2012).

5. Aune D, Chan DS, Vieira AR, Navarro Rosenblatt DA, Vieira R, Greenwood DC and Norat T, Dietary compared with blood concentrations of carotenoids and breast cancer risk: a systematic review and meta-analysis of prospective studies. Am. J Clin Nutr 96:356-373 (2012). 
6. BhattRP B and KumarN H, combining ability and genetics for vitamin C, total soluble solids and yield in tomato (Lycopersicon esculentum) at $1700 \mathrm{~m}$ altitude. J Agric Sci 137:71-75 (2001).

7. Bino RJ, De Vos CHR, Lieberman M, Hall RD, Bovy A, Jonker HH, Tikunov Y, Lommen A, Moco S and Levin I, The light-hyperresponsive high pigment-2dg mutation of tomato: alterations in the fruit metabolome. New Phytol 166:427-438 (2005).

8. Bruhn CM, Feldman N, Garlitz C, Harwood J, Ivans E, Marshall M, Riley A, Thurber D and Williamson E, Consumer perceptions of quality: Aprocots, cantaloupes, peaches, pears, strawberries and tomatoes. J Food Qual 14:187-195 (1991).

9. Casals J, Pascual L, Cañizares J, Cebolla-Cornejo J, Casañas F and Nuez F, The risks of success in quality vegetable markets: Possible genetic erosion in Marmande tomatoes (Solanum lycopersicum L.) and consumer dissatisfaction. Sci Hortic 130:78-84 (2011).

10. Cebolla-Cornejo J, Soler S and Nuez F, Genetic erosion of traditional varieties of vegetable crops in Europe: tomato cultivation in Valencia (Spain) as a case Study. Int J Plant Prod 1:113-128 (2007).

11. Cebolla-Cornejo J, Roselló S, Valcárcel M, Serrano E, Beltrán J and Nuez F, Evaluation of Genotype and Environment Effects on Taste and Aroma Flavor Components of Spanish Fresh Tomato Varieties. J Agric Food Chem 59:2440-2450 (2011).

12. Davey MW, Montagu MV, Inzé D, Sanmartin M, Kanellis A, Smirnoff N, Benzie IJ, Strain JJ, Favell D and Fletcher J, Plant L-ascorbic acid: chemistry, function, metabolism, bioavailability and effects of processing. J Sci Food Agric 80:825-860 (2000).

13. Davies JN and Hobson GE, The constituents of tomato fruit - the influence of environment, nutrition, and genotype. Crit Rev Food Sci Nutr 15:205-280 (1981). 
14. Dumas Y, Dadomo M, Di Lucca G and Grolier P, Effects of environmental factors and agricultural techniques on antioxidantcontent of tomatoes. J Sci Food Agric 83:369-382 (2003).

15. Galiana-Balaguer L, Roselló S, Herrero-Martínez JM, Maquieira A and Nuez F, Determination of L-Ascorbic Acid in Lycopersicon Fruits by Capillary Zone Electrophoresis. Anal Biochem 296:218-224 (2001).

16. Gallie DR, The role of 1-ascorbic acid recycling in responding to environmental stress and in promoting plant growth. J Exp Bot 64:433-443 (2013).

17. García-Plazaola JI and Becerril JM, A rapid high-performance liquid chromatography method to measure lipophilic antioxidants in stressed plants: simultaneous determination of carotenoids and tocopherols. Phytochem Anal 10:307-313 (1999).

18. George B, Kaur C, Khurdiya DS and Kapoor HC, Antioxidants in tomato (Lycopersium esculentum) as a function of genotype. Food Chem 84:45-51 (2004).

19. Giovannucci E, Tomatoes, Tomato-Based Products, Lycopene, and Cancer: Review of the Epidemiologic Literature. J Natl Cancer Inst 91:317-331 (1999).

20. Goldman IL, Molecular breeding of healthy vegetables. EMBO Rep 12:96-102 (2011).

21. Gould WA, Tomato Production, Processing and Technology. CTI Publications, Baltimore (1992).

22. Granato D, Branco GF, Nazzaro F, Cruz AG and Faria JAF, Functional Foods and Nondairy Probiotic Food Development: Trends, Concepts, and Products. Compr Rev Food Sci Food Saf 9:292-302 (2010).

23. Hamner KC, Bernstein L and Maynard LA, Effects of Light Intensity, Day Length, Temperature, and Other Environmental Factors on the Ascorbic Acid Content of Tomatoes. J Nutr 29:85-97 (1945). 
24. Holden JM, Eldridge AL, Beecher GR, Marilyn Buzzard I, Bhagwat S, Davis CS, Douglass LW, Gebhardt S, Haytowitz D and Schakel S, Carotenoid Content of U.S. Foods: An Update of the Database. J Food Compos Anal 12:169-196 (1999).

25. Ilahy R, Hdider C, Lenucci MS, Tlili I and Dalessandro G, Antioxidant activity and bioactive compound changes during fruit ripening of high-lycopene tomato cultivars. J Food Compos Anal 24:588-595 (2011).

26. Jones PJ and Jew S, Functional food development: concept to reality. Trends Food Sci Technol 18:387-390 (2007).

27. Kavanaugh CJ, Trumbo PR and Ellwood KC, The U.S. Food and Drug Administration's Evidence-Based Review for Qualified Health Claims: Tomatoes, Lycopene, and Cancer. $J$ Natl Cancer Inst 99:1074-1085 (2007).

28. Krystallis A, Maglaras G and Mamalis S, Motivations and cognitive structures of consumers in their purchasing of functional foods. Food Qual Prefer 19:525-538 (2008).

29. Leiva-Brondo M, Valcárcel M, Cortés-Olmos C, Roselló S, Cebolla-Cornejo J and Nuez F, Exploring alternative germplasm for the development of stable high vitamin $\mathrm{C}$ content in tomato varieties. Sci Hortic (2011).

30. Lenucci MS, Cadinu D, Taurino M, Piro G and Dalessandro G, Antioxidant Composition in Cherry and High-Pigment Tomato Cultivars. J Agric Food Chem 54:2606-2613 (2006).

31. Levin I, Lalazar A, Bar M and Schaffer AA, Non GMO fruit factories: Strategies for modulating metabolic pathways in the tomato fruit. Industrial Crops and Products 20:29-36 (2004).

32. Lin J, Cook NR, Albert C, Zaharris E, Gaziano JM, Van Denburgh M, Buring JE and Manson JE, Vitamins C and E and Beta Carotene Supplementation and Cancer Risk: A Randomized Controlled Trial. J Natl Cancer Inst 101:14-23 (2009). 
33. Martínez-Valverde I, Periago MJ, Provan G and Chesson A, Phenolic compounds, lycopene and antioxidant activity in commercial varieties of tomato (Lycopersicum esculentum). $J$ Sci Food Agric 82:323-330 (2002).

34. Menrad K, Market and marketing of functional food in Europe. J Food Eng 56:181-188 (2003).

35. Mente A, de Koning L, Shannon HS and Anand SS, A systematic review of the evidence supporting a causal link between dietary factors and coronary heart disease. Arch Intern Med 169:659-669 (2009).

36. Mignone LI, Giovannucci E, Newcomb PA, Titus-Ernstoff L, Trentham-Dietz A, Hampton JM, Willett WC and Egan KM, Dietary carotenoids and the risk of invasive breast cancer. Int J Cancer 124:2929-2937 (2009).

37. Palace VP, Khaper N, Qin Q and Singal PK, Antioxidant potentials of vitamin A and carotenoids and their relevance to heart disease. Free Radic Biol Med 26:746-761 (1999).

38. Raffo A, Malfa GL, Fogliano V, Maiani G and Quaglia G, Seasonal variations in antioxidant components of cherry tomatoes (Lycopersicon esculentum cv. Naomi F1). J Food Comp Anal 19:11-19 (2006).

39. Rao AV, Lycopene, Tomatoes, and the Prevention of Coronary Heart Disease. Exp Biol Med 227:908-913 (2002).

40. Roselló S, Adalid AM, Cebolla-Cornejo J and Nuez F, Evaluation of the genotype, environment and their interaction on carotenoid and ascorbic acid accumulation in tomato germplasm. J Sci Food Agric 91:1014-1021 (2011).

41. Sacks EJ and Francis DM, Genetic and Environmental Variation for Tomato Flesh Color in a Population of Modern Breeding Lines. J Amer Soc Hort Sci 126:221-226 (March 2001).

42. Shi J and Maguer ML, Lycopene in Tomatoes: Chemical and Physical Properties Affected by Food Processing. Crit Rev Food Sci Nutr 40:1-42 (2000). 
43. Stevens MA and Rick CM, Genetics and breeding, in The tomato crop, Anonymous Springer, pp. 35-109 (1987).

44. Stevens R, Buret M, Duffé P, Garchery C, Baldet P, Rothan C and Causse M, Candidate Genes and Quantitative Trait Loci Affecting Fruit Ascorbic Acid Content in Three Tomato Populations. Plant Physiol 143:1943-1953 (April 2007).

45. Sun-Waterhouse D, The development of fruit-based functional foods targeting the health and wellness market: a review. Int J Food Sci Tech 46:899-920 (2011).

46. Tomes ML and Quackenbush FW, Caro-red, a new provitamin a rich tomato. Econ Bot 12:256-260 (1958).

47. Toor RK, Savage GP and Lister CE, Seasonal variations in the antioxidant composition of greenhouse grown tomatoes. J Food Comp Anal 19:1-10 (2006).

48. van Poppel G and Goldbohm RA, Epidemiologic evidence for beta-carotene and cancer prevention. Amer J Clil Nutr 62:1393S-1402S (1995).

49. Watada AE, Aulenbach BB and Worthington JT, Vitamins A and C in ripe tomatoes as affected by stage of ripeness at harvest and by supplementary ethylene. J Food Sci 41:856858 (1976).

50. Ziegler R, A review of epidemiologic evidence that carotenoids reduce the risk of cancer. J Nutr 119:116-122 (1989). 
Table 1. Description of the varieties and origin of the populations evaluated (varietal code in parentheses).

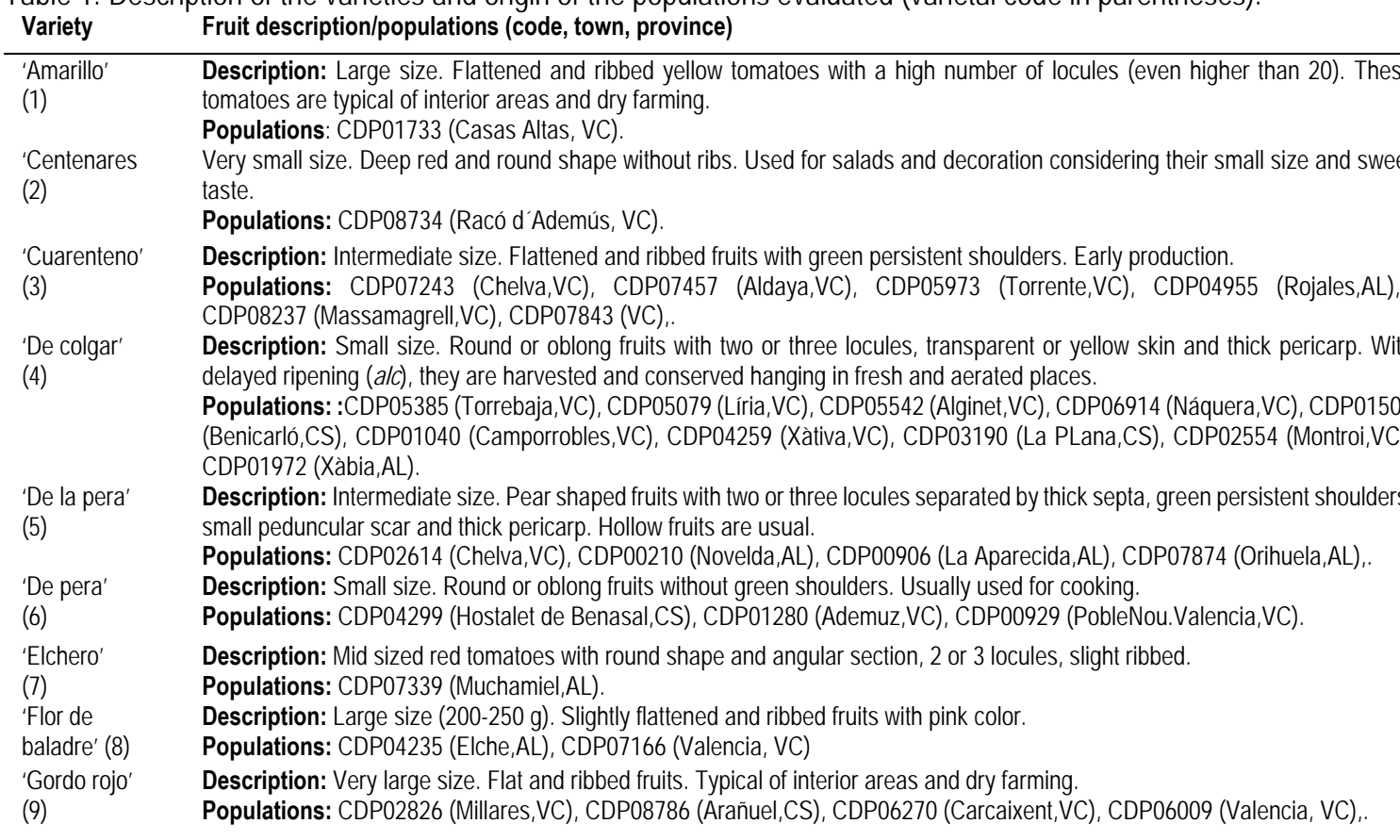

'Muchamiel' Description: Large size. Flat and strong ribbed fruits, numerous locules, big peduncular scar with an important corky area, hard (10) and heavy pericarp and moderate radial cracking. Green shoulders, orange-red ripe color. It is a late variety. Populations: CDP05658 (Novelda,AL), CDP04133 (La Aparecida,AL), CDP05229 (Viver,CS), CDP00155 (Elche,AL), CDP07582 (San Juan,AL), CDP08091 (Campello,AL), CDP00700 (Muchamiel,AL), CDP01469 (San Juan,AL), CDP07889 (Buñol,VC), CDP08014 (San Juan,AL), CDP01988 (Muchamiel,AL), CDP09344 (Muchamiel,AL), CDP02195 (Muchamiel,AL), CDP08780 (Muchamiel,AL), CDP08427 (Muchamiel,AL), CDP07052 (Muchamiel,AL), CDP00386 (Muchamiel,AL), CDP04512 (Muchamiel,AL), CDP05422 (Muchamiel,AL), CDP00604 (Muchamiel,AL), CDP03096 (Orihuela,AL), CDP01971 (San Juan,AL), CDP05938 (Alboraya,VC), CDP01138 (San Juan,AL), CDP01746 (Orihuela,AL), CDP08999 (San Juan de Alicante,AL), CDP08761 (Catarroja,VC), CDP09432 (Llíria,VC).

'Negre' Description: Large size. Intense purple coloration. Fruits are flat and slightly ribbed.

(11) Populations: CDP02095 (Torrent,VC)

'Pimiento' Description: Intermediate size. Elongated fruits (similar to "Italian" peppers), green persistent shoulders, two to four locules and (12) moderate radial cracking. Used for cooking, deep red flesh and reduced number of seeds. Populations: CDP06083 (Venta del Moro,VC), CDP04079 (Jérica,CS), CDP06446 (Fontanares,VC), CDP05734 (Villahermosa del Río,CS), CDP01712 (Alborache,VC), CDP04056 (Catarroja,VC), CDP02391 (Moncada,VC), CDP08320 (Massamagrell,VC).

'Redondo rojo' Description: Intermediate - large size. Includes rounded, smooth red colored tomatoes.

(13) Populations: CDP07064 (Sueca,VC), CDP04562 (Carcaixent,VC).

'Rosa' Description: Very large size. Flat or slightly flat fruits with intense ribbing. Transparent skin, and pink colour. Typical of interior (14) areas and dry farming.

Populations: CDP08690 (Fontanares,VC), CDP05702 (Castillo de Villamalefa,CS), CDP04903 (Onda,CS), CDP00764 (Aras del Alpuente,VC), CDP01302 (Rincón de Ademuz,VC), CDP09459 (Yátova,VC), CDP04904 (Alboraya,VC), CDP05992 (Requena,VC), CDP07661 (Todolella,CS), CDP03526 (Sellent,VC), CDP04303 (Valencia, VC), CDP04008 (Valencia, VC).

'Tres cantos' Description: Large size. Round shape and angular section. Red and smooth fruits, without low number of locules considering (15) their size.

Populations: CDP06491 (Carcaixent,VC).

'Valenciano' Description: Intermediate size. This varietal type show two different subtypes: "Masclet" and "Blanca" subtypes. "Masclet" (16) (conventional "Valenciano" type) show a smaller size, hearted shape. "Blanca" show a bigger size, slightly flattened and hearted shape, and paler color in the immature fruits. Both with green shoulders, orange-red ripe color and numerous locules. Usually moderate radial and circular cracking is present.

Populations: CDP07303 (Valencia,VC), CDP01509 (SietaAguas,VC), CDP04333 (Picassent,VC), CDP01090 (Segorbe,CS), CDP00616 (Líria,VC), CDP02722 (Segorbe,CS), CDP05254 (Alboraya,VC), CDP06161 (Villena,AL), CDP05260 (Turís,VC), CDP07291 (Valencia,VC), CDP08276 (Sueca,VC), CDP01343 (Foios,VC), CDP04640 (Vinalesa,VC), CDP00623 (Moncada,VC), CDP04486 (L'Alcudia de Crespins,VC), CDP04829 (Pobla de Vallbona,VC), CDP09978 (Valencia, VC), CDP08151 (Valencia, VC), CDP02310 (Morella,CS), CDP00450 (PobleNou.Valencia,VC), CDP07489 (Segorbe,CS), CDP00960 (Villargordo del Cabriel,VC), CDP04423 (Museros,VC), CDP04372(SieteAguas,VC), CDP02109 (VC), CDP05333 (Almenara,CS), CDP05691 (Vinaroz,CS), CDP00142 (Valencia, VC), CDP05729 (El Pereió,VC), CDP01649 (Picassent,VC), CDP01949 (Valencia, VC), CDP08595 (Meliana,VC), CDP02589 (Murod'Alcoi,AL), CDP04915 (Carcaixent,VC), CDP02182 (ViverosTaxes,LN), CDP04052 (ViverosCucala,LN), CDP06753 (ViverosPeris,LN), , CDP01197 (Valencia, VC), CDP01646 (Valencia, VC), CDP05266 (Valencia, VC), CDP03596 (Valencia, VC), CDP07231 (Valencia, VC),.

VC: Valencia; CS: Castellón; AL: Alicante; LN: local nurseries. 
Table 2. Correlations between functional compounds and morphological traits (only significant correlations higher than 0.2 are shown; $\mathrm{p}$-values in parentheses).

\section{B -carotene
Lycopene}

Lycopene

Hunter a

Hunter b

Hunter a/b

Hunter L

Fruit height

Fruit width/height ratio

Fruit core width/Fruit width ratio

Fruit width

Fruit core width

Pericarp thickness

Pericarp thickness/Fruit width ratio

Number of locules

Fruit weight Lycopene Ascorbic acid

$B$-carotene

$-0.26(0.004)$

$0.47(0.000)$

$-0.30(0.000)$

$0.53(0.00)$

$-0.55(0.000)$

$-0.27(0.003) \quad 0.25(0.006)$

$-0.39(0.000)$

$-0.28(0.001)$

$-0.28(0.002) \quad-0.28(0.001)$

$-0.36(0.000)$

$0.21(0.02)$

$-0.31(0.000)$

$-0.26(0.004)$
$-0.23(0.012)$

$-0.24(0.006)$

$-0.25(0.004)$

$-0.21(0.017)$ 
Table 3. $\beta$-carotene, lycopene and ascorbic acid contents $\left(\mathrm{mg} \mathrm{kg}^{-1} \mathrm{fw}\right)$ and coefficients of variation detected in evaluated populations. For each population variety is indicated in parentheses (refer to table 1).

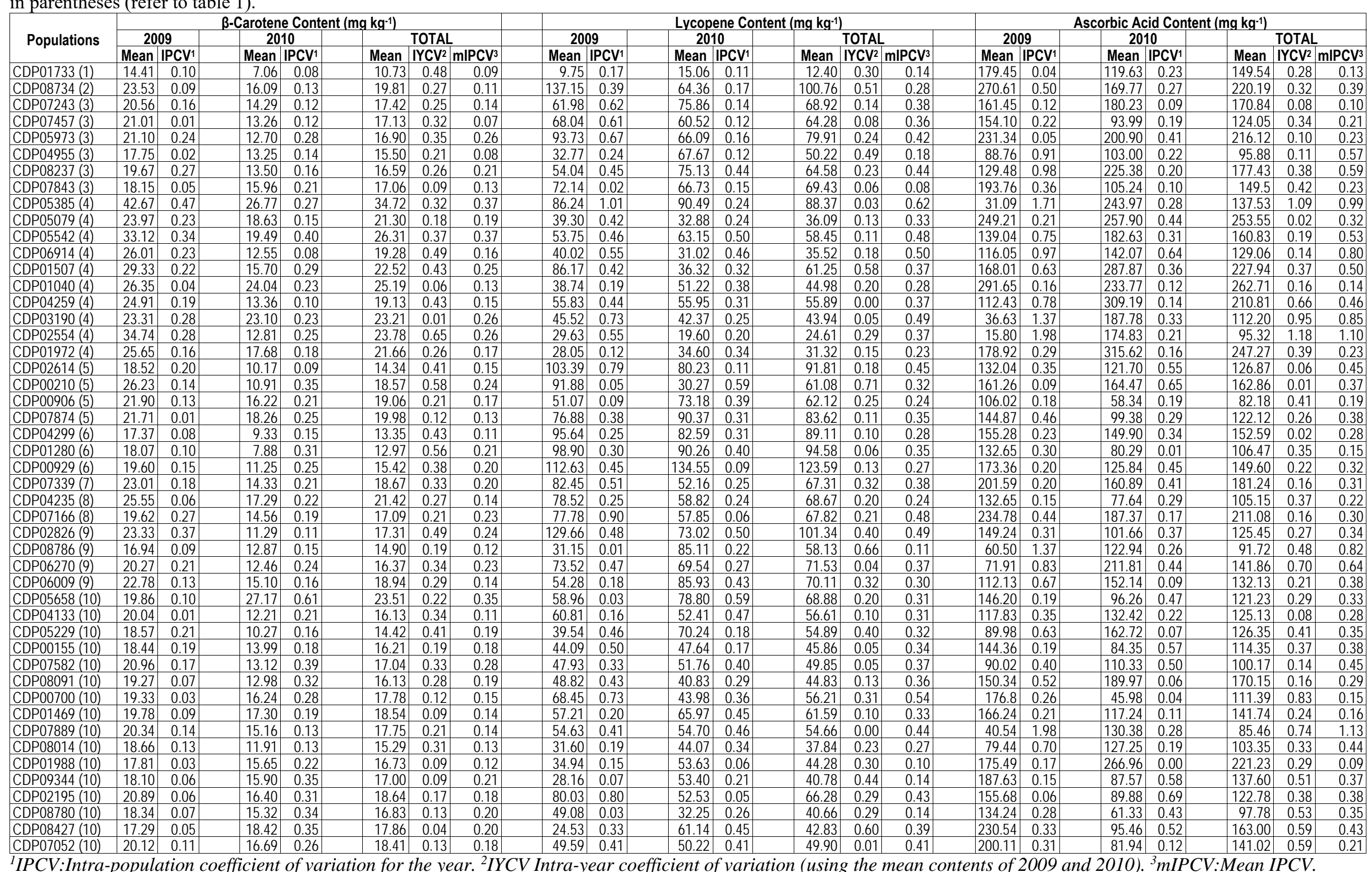


Table 3. $\beta$-carotene, lycopene and ascorbic acid contents $\left(\mathrm{mg} \mathrm{kg}^{-1}\right)$ and coefficients of variation detected in evaluated populations. For each population variety is indicated in parentheses (refer to table 1).

\begin{tabular}{|c|c|c|c|c|c|c|c|c|c|c|c|c|c|c|c|c|c|c|c|c|c|}
\hline \multirow{3}{*}{ Populations } & \multicolumn{7}{|c|}{$\beta$-Carotene Content $\left(\mathrm{mg} \mathrm{kg}^{-1}\right)$} & \multicolumn{7}{|c|}{ Lycopene Content $\left(\mathrm{mg} \mathrm{kg}^{-1}\right)$} & \multicolumn{7}{|c|}{ Ascorbic Acid Content $\left(\mathrm{mg} \mathrm{kg}^{-1}\right)$} \\
\hline & \multirow{2}{*}{\multicolumn{2}{|c|}{2009}} & \multicolumn{2}{|c|}{2010} & \multirow{2}{*}{\multicolumn{3}{|c|}{$\begin{array}{c}\text { TOTAL } \\
\text { Mean } \mid \mathrm{YCV}^{2} / \mathrm{m} \mathrm{PCV}^{3}\end{array}$}} & \multicolumn{2}{|c|}{\begin{tabular}{|l|}
2009 \\
\end{tabular}} & \multirow{2}{*}{\multicolumn{2}{|c|}{\begin{tabular}{|c|}
2010 \\
Mean IIPCV 1 \\
\end{tabular}}} & \multirow{2}{*}{ Mean I } & \multicolumn{2}{|c|}{\begin{tabular}{l|l} 
TOTAL \\
\end{tabular}} & \multirow{2}{*}{\multicolumn{2}{|c|}{2009}} & \multicolumn{2}{|c|}{2010} & & TOTAL & \\
\hline & Mean & & Mean & IPCV 1 & Mean & & & Mean I & IPCV 1 & & & & IYCV ${ }^{2}$ & $\mathrm{mIPCV}^{3}$ & & PCV 1 & Mean II & PCV1 & Mean & IYCV ${ }^{2}$ & $\mathrm{mIPCV}^{3}$ \\
\hline CDP00386 (10) & 28.71 & 0.10 & 11.51 & 0.21 & 20.11 & 0.60 & \begin{tabular}{|l|}
0.15 \\
\end{tabular} & 82.74 & 0.25 & 33.85 & 0.54 & 58.30 & 0.59 & 0.39 & 142.93 & 0.28 & 116.00 & 0.37 & 129.46 & 0.15 & 0.33 \\
\hline CDP04512 (10) & 19.10 & 0.06 & 15.37 & 0.19 & 17.24 & 0.15 & 0.12 & 50.02 & 0.18 & 66.06 & 0.11 & 58.04 & 0.20 & 0.14 & 203.78 & 0.05 & 87.04 & 0.29 & 145.41 & 0.57 & 0.17 \\
\hline CDP05422 (10) & 16.47 & 0.17 & 14.18 & 0.30 & 15.32 & 0.11 & 0.23 & 27.62 & 0.06 & 59.64 & 0.80 & 43.63 & 0.52 & 0.43 & 185.02 & 0.11 & 60.59 & 0.17 & 122.81 & 0.72 & 0.14 \\
\hline CDP00604 (10) & 20.75 & 0.09 & 14.91 & 0.30 & 17.83 & 0.23 & 0.19 & 58.31 & 0.10 & 58.17 & 0.13 & 58.24 & 0.00 & 0.12 & 143.41 & 0.20 & 76.00 & 0.32 & 109.71 & 0.43 & 0.26 \\
\hline CDP03096 (10) & 20.50 & 0.09 & 14.65 & 0.12 & 17.58 & 0.24 & 0.10 & 57.71 & 0.31 & 46.34 & 0.48 & 52.02 & 0.15 & 0.40 & 132.65 & 0.31 & 87.19 & 0.59 & 109.92 & 0.29 & 0.45 \\
\hline CDP01971 (10) & 17.67 & 0.12 & 12.26 & 0.07 & 14.96 & 0.26 & 0.09 & 51.25 & 0.49 & 30.67 & 0.16 & 40.96 & 0.36 & 0.33 & 145.26 & 0.03 & 55.21 & 0.40 & 100.24 & 0.64 & 0.21 \\
\hline CDP05938 (10) & 22.20 & 0.10 & 13.80 & 0.15 & 18.00 & 0.33 & 0.12 & 63.11 & 0.38 & 37.51 & 0.18 & 50.31 & 0.36 & 0.28 & 103.80 & 0.71 & 96.19 & 0.78 & 99.99 & 0.05 & 0.75 \\
\hline CDP01138 (10) & 19.40 & 0.00 & 16.56 & 0.40 & 17.98 & 0.11 & 0.20 & 44.56 & 0.15 & 51.10 & 0.25 & 47.83 & 0.10 & 0.20 & 169.90 & 0.24 & 210.31 & 0.18 & 190.10 & 0.15 & 0.21 \\
\hline CDPO1746 (10) & 18.22 & 0.10 & 17.00 & 0.07 & 17.61 & 0.05 & 0.08 & 41.49 & 0.58 & 48.53 & 0.21 & 45.01 & 0.11 & 0.40 & \begin{tabular}{|l|}
139.07 \\
\end{tabular} & 0.15 & 74.95 & 0.43 & 107.01 & 0.42 & 0.29 \\
\hline CDP08999 (10) & 20.17 & 0.16 & 15.11 & 0.04 & 17.64 & 0.20 & 0.10 & 65.43 & 0.49 & 60.56 & 0.46 & 63.00 & 0.05 & 0.48 & $\mid 196.76$ & 0.22 & 140.61 & 0.41 & 168.68 & 0.24 & 0.31 \\
\hline CDP08761 (10) & 18.99 & 0.07 & 11.61 & 0.07 & 15.3 & 0.34 & 0.07 & 49.88 & 0.49 & 44.91 & 0.34 & 47.39 & 0.07 & 0.41 & 84.19 & 1.19 & 167.99 & 0.75 & 126.09 & 0.47 & 0.97 \\
\hline CDP09432 (10) & 22.92 & 0.28 & 12.78 & 0.09 & 17.85 & 0.40 & 0.19 & 121.95 & 0.58 & 35.15 & 0.05 & 78.55 & 0.78 & 0.32 & 162.31 & 0.22 & 105.92 & 0.15 & 134.11 & 0.30 & 0.19 \\
\hline CDP02095 (11) & 18.39 & 0.07 & 11.61 & 0.28 & 15.00 & 0.32 & 0.17 & 41.33 & 0.18 & 54.89 & 0.25 & 48.11 & 0.20 & 0.21 & 149.11 & 0.29 & 219.80 & 0.37 & 184.45 & 0.27 & 0.33 \\
\hline CDP06083 (12) & 19.89 & 0.11 & 12.21 & 0.23 & 16.05 & 0.34 & 0.17 & 152.20 & 0.77 & 112.24 & 0.32 & 132.22 & 0.21 & 0.54 & 32.52 & 1.16 & 112.97 & 0.41 & 72.74 & 0.78 & 0.78 \\
\hline CDP04079 (12) & 17.25 & 0.08 & 11.69 & 0.30 & 14.47 & 0.27 & 0.19 & 51.98 & 0.57 & 107.25 & 0.26 & 79.62 & 0.49 & 0.42 & \begin{tabular}{|l|}
107.39 \\
\end{tabular} & 1.02 & 178.35 & 0.58 & 142.87 & 0.35 & 0.80 \\
\hline CDP06446 (12) & 19.07 & 0.21 & 10.98 & 0.38 & 15.02 & 0.38 & 0.30 & 78.67 & 0.35 & 78.52 & 0.75 & 78.59 & 0.00 & 0.55 & 191.26 & 0.35 & 116.69 & 0.59 & 153.97 & 0.34 & 0.47 \\
\hline CDP05734 (12) & 17.62 & 0.13 & 11.84 & 0.20 & 14.73 & 0.28 & 0.17 & 63.49 & 0.25 & 97.19 & 0.32 & 80.34 & 0.30 & 0.28 & \begin{tabular}{|l|}
138.39 \\
\end{tabular} & 0.18 & 108.77 & 0.48 & 123.58 & 0.17 & 0.33 \\
\hline CDP01712 (12) & 20.49 & 0.17 & 13.33 & 0.06 & 16.91 & 0.30 & 0.12 & 94.33 & 0.62 & 89.23 & 0.17 & 91.78 & 0.04 & 0.39 & $\mid 196.38$ & 0.35 & \begin{tabular}{|c|}
93.47 \\
\end{tabular} & 0.29 & 144.92 & 0.50 & 0.32 \\
\hline CDPO4056 (12) & 19.30 & 0.09 & 14.57 & 0.17 & 16.93 & 0.20 & 0.13 & 118.53 & 0.23 & 112.26 & 0.09 & 115.40 & 0.04 & 0.16 & 78.55 & 1.23 & 72.38 & 0.45 & 75.47 & 0.06 & 0.84 \\
\hline CDP02391 (12) & 20.43 & 0.17 & 10.38 & 0.21 & 15.41 & 0.46 & 0.19 & 58.42 & 0.40 & $\begin{array}{l}78.02 \\
\end{array}$ & 0.30 & 68.22 & 0.20 & 0.35 & 132.77 & 0.22 & 161.09 & 0.56 & 146.93 & 0.14 & 0.39 \\
\hline CDP08320 (12) & 19.47 & 0.17 & 9.94 & 0.25 & 14.70 & 0.46 & 0.21 & 85.98 & 0.64 & 96.17 & 0.38 & 91.08 & 0.08 & 0.51 & 202.83 & 0.10 & 120.78 & 0.13 & 161.81 & 0.36 & 0.11 \\
\hline CDP07064 (13) & 38.55 & 0.46 & 24.53 & 0.25 & 31.54 & 0.31 & 0.36 & 94.64 & 0.51 & 76.76 & 0.15 & 85.70 & 0.15 & 0.33 & 117.36 & 0.23 & 126.22 & 0.28 & 121.79 & 0.05 & 0.25 \\
\hline CDPO4562 (13) & 24.01 & 0.01 & 13.26 & 0.15 & 18.63 & 0.41 & 0.08 & 112.13 & 0.46 & 46.35 & 0.33 & 79.24 & 0.59 & 0.39 & 133.84 & 0.91 & 96.22 & 0.29 & 115.03 & 0.23 & 0.60 \\
\hline CDP08690 (14) & 16.31 & 0.11 & 10.25 & 0.36 & 13.28 & 0.32 & 0.23 & 30.81 & 0.33 & 53.10 & 0.53 & 41.96 & 0.38 & 0.43 & \begin{tabular}{|l|}
154.07 \\
\end{tabular} & 0.13 & 133.17 & 0.23 & 143.62 & 0.10 & 0.18 \\
\hline CDP05702 (14) & 17.08 & 0.05 & 12.03 & 0.08 & 14.56 & 0.25 & 0.06 & 31.52 & 0.18 & 75.21 & 0.31 & 53.37 & 0.58 & 0.25 & 161.28 & 0.57 & 187.38 & 0.39 & 174.33 & 0.11 & 0.48 \\
\hline CDPO4903 (14) & 20.46 & 0.10 & 9.66 & 0.20 & 15.06 & 0.51 & 0.15 & 58.08 & 0.20 & 55.61 & 0.34 & 56.84 & 0.03 & 0.27 & \begin{tabular}{|l|}
33.68 \\
\end{tabular} & 1.08 & 106.71 & 0.57 & 70.19 & 0.74 & 0.82 \\
\hline CDP00764 (14) & 20.41 & 0.15 & 11.63 & 0.06 & 16.02 & 0.39 & 0.10 & 43.55 & 0.16 & 74.65 & 0.62 & 59.10 & 0.37 & 0.39 & 21.16 & 1.15 & 124.09 & 0.36 & 72.63 & 1.00 & 0.76 \\
\hline CDP01302 (14) & 18.37 & 0.00 & 12.54 & 0.13 & 15.46 & 0.27 & 0.06 & 34.68 & 0.27 & 73.42 & 0.41 & 54.05 & 0.51 & 0.34 & 0.00 & 0.00 & 114.82 & 0.92 & 57.41 & 1.41 & 0.46 \\
\hline CDP09459 (14) & 19.98 & 0.36 & 13.00 & 0.03 & 16.49 & 0.30 & 0.19 & 79.17 & 0.95 & 85.00 & 0.35 & 82.08 & 0.05 & 0.65 & 146.74 & 0.42 & 237.67 & 0.30 & 192.20 & 0.33 & 0.36 \\
\hline CDPO4904 (14) & 19.45 & 0.03 & 11.55 & 0.14 & 15.50 & 0.36 & 0.09 & 90.95 & 0.40 & 71.99 & 0.19 & 81.47 & 0.16 & 0.29 & 190.61 & 0.05 & 122.70 & 0.29 & 156.65 & 0.31 & 0.17 \\
\hline CDP05992 (14) & 18.06 & 0.17 & 10.01 & 0.23 & 14.03 & 0.41 & 0.20 & 39.63 & 0.71 & 60.36 & 0.41 & 50.00 & 0.29 & 0.56 & 38.85 & 1.16 & 96.46 & 0.47 & 67.66 & 0.60 & 0.82 \\
\hline CDP07661 (14) & 15.52 & 0.06 & 7.95 & 0.26 & 11.73 & 0.46 & 0.16 & 22.86 & 0.27 & 42.31 & 0.43 & 32.58 & 0.42 & 0.35 & 62.25 & 0.86 & 124.26 & 0.76 & 93.26 & 0.47 & 0.81 \\
\hline CDP03526 (14) & 16.99 & 0.14 & 10.86 & 0.25 & 13.93 & 0.31 & 0.19 & 97.12 & 0.51 & 101.57 & 0.60 & 99.35 & 0.03 & 0.56 & \begin{tabular}{|l|}
85.89 \\
\end{tabular} & 0.63 & 64.21 & 0.46 & 75.05 & 0.20 & 0.54 \\
\hline CDPO4303 (14) & 22.47 & 0.00 & 12.08 & 0.02 & 17.27 & 0.43 & 0.01 & 229.54 & 0.51 & 74.32 & 0.37 & 151.93 & 0.72 & 0.44 & 142.28 & 0.42 & 168.83 & 0.68 & 155.56 & 0.12 & 0.55 \\
\hline CDPO4008 (14) & 16.67 & 0.06 & 12.41 & 0.25 & 14.54 & 0.21 & 0.15 & 61.73 & 0.02 & 82.02 & 0.28 & 71.87 & 0.20 & 0.15 & 210.32 & 0.08 & 156.18 & 0.35 & 183.25 & 0.21 & 0.21 \\
\hline CDP06491 (15) & 21.18 & 0.18 & 10.65 & 0.10 & 15.92 & 0.47 & 0.14 & 48.43 & 0.44 & 54.24 & 0.31 & 51.33 & 0.08 & 0.38 & 113.51 & 0.30 & 126.39 & 0.84 & 119.95 & 0.08 & 0.57 \\
\hline CDPO7303 (16) & 21.45 & 0.19 & 15.79 & 0.15 & 18.62 & 0.22 & 0.17 & 73.64 & 0.61 & 90.61 & 0.22 & 82.12 & 0.15 & 0.42 & 153.40 & 0.15 & 100.70 & 0.41 & 127.05 & 0.29 & 0.28 \\
\hline CDP01509 (16) & 19.56 & 0.06 & 10.32 & 0.30 & 14.94 & 0.44 & 0.18 & 81.27 & 0.16 & 42.29 & 0.18 & 61.78 & 0.45 & 0.17 & 131.42 & 0.17 & 55.91 & 0.16 & 93.67 & 0.57 & 0.17 \\
\hline CDPO4333 (16) & 19.53 & 0.16 & 12.73 & 0.22 & 16.13 & 0.30 & 0.19 & 65.20 & 0.49 & 81.20 & 0.30 & 73.20 & 0.15 & 0.40 & \begin{tabular}{|l|}
14.99 \\
\end{tabular} & 1.99 & 134.31 & 0.51 & 74.65 & 1.13 & 1.25 \\
\hline CDP01090 (16) & 21.50 & 0.04 & 11.51 & 0.51 & 16.50 & 0.43 & 0.28 & 50.52 & 0.42 & 62.83 & 0.48 & 56.68 & 0.15 & 0.45 & \begin{tabular}{|l|}
81.78 \\
\end{tabular} & 0.25 & 133.10 & 0.54 & 107.44 & 0.34 & 0.40 \\
\hline CDP00616 (16) & 20.12 & 0.14 & 14.12 & 0.16 & 17.12 & 0.25 & 0.15 & 74.17 & 0.15 & 72.62 & 0.40 & 73.40 & 0.01 & 0.27 & 49.01 & 1.09 & 76.58 & 0.49 & 62.79 & 0.31 & 0.79 \\
\hline CDP02722 (16) & 19.27 & 0.11 & 10.51 & 0.20 & 14.89 & 0.42 & 0.15 & 54.70 & 0.36 & 50.27 & 0.30 & 52.48 & 0.06 & 0.33 & 112.92 & 0.08 & 143.58 & 0.51 & 128.25 & 0.17 & 0.29 \\
\hline CDP05254 (16) & 18.90 & 0.08 & 15.36 & 0.33 & 17.13 & 0.15 & 0.20 & 55.10 & 0.27 & 83.48 & 0.30 & 69.29 & 0.29 & 0.28 & 160.95 & 0.25 & 159.23 & 0.20 & 160.09 & 0.01 & 0.22 \\
\hline CDP06161 (16) & 20.97 & 0.16 & 14.84 & 0.16 & 17.90 & 0.24 & 0.16 & 62.73 & 0.38 & 79.75 & 0.32 & 71.24 & 0.17 & 0.35 & \begin{tabular}{|r|}
63.63 \\
\end{tabular} & 0.92 & 135.34 & 0.13 & 99.49 & 0.51 & 0.53 \\
\hline CDP05260 (16) & 19.89 & 0.10 & 12.08 & 0.24 & 15.99 & 0.35 & 0.17 & 62.77 & 0.31 & 58.80 & 0.22 & 60.79 & 0.05 & 0.26 & 115.21 & 0.51 & 150.13 & 0.21 & 132.67 & 0.19 & 0.36 \\
\hline CDP07291 (16) & 19.24 & 0.23 & 10.69 & 0.38 & 14.97 & 0.40 & 0.30 & 55.43 & 0.70 & 56.71 & 0.51 & 56.07 & 0.02 & 0.61 & 76.49 & 0.53 & 248.24 & 0.22 & 162.36 & 0.75 & 0.37 \\
\hline CDP08276 (16) & 18.91 & 0.14 & 18.69 & 0.10 & 18.80 & 0.01 & 0.12 & 39.83 & 0.04 & 90.87 & 0.17 & 65.35 & 0.55 & 0.11 & 191.77 & 0.07 & 102.39 & 0.21 & 147.08 & 0.43 & 0.14 \\
\hline CDP01343 (16) & 21.13 & 0.17 & 13.56 & 0.13 & 17.35 & 0.31 & 0.15 & 66.52 & 0.38 & 62.93 & 0.31 & 64.73 & 0.04 & 0.34 & \begin{tabular}{|l|}
107.48 \\
\end{tabular} & 0.40 & 157.91 & 0.61 & 132.69 & 0.27 & 0.51 \\
\hline
\end{tabular}


Table 3 (cont.). $\beta$-carotene, lycopene and ascorbic acid contents $\left(\mathrm{mg} \mathrm{kg}^{-1} \mathrm{fw}\right)$ and coefficients of variation detected in evaluated populations. For each population variety is indicated in parentheses (refer to table 1).

\begin{tabular}{|c|c|c|c|c|c|c|c|c|c|c|c|c|c|c|c|c|c|c|c|c|c|}
\hline \multirow{3}{*}{ Populations } & \multicolumn{7}{|c|}{$\beta$-Carotene Content $\left(\mathrm{mg} \mathrm{kg}^{-1}\right)$} & \multicolumn{7}{|c|}{ Lycopene Content $\left(\mathrm{mg} \mathrm{kg}^{-1}\right)$} & \multicolumn{7}{|c|}{ Ascorbic Acid Content (mg kg-1) } \\
\hline & \multicolumn{2}{|c|}{2009} & \multicolumn{2}{|c|}{2010} & \multicolumn{3}{|c|}{ TOTAL } & \multicolumn{2}{|c|}{2009} & \multicolumn{2}{|c|}{2010} & \multicolumn{3}{|c|}{ TOTAL } & \multicolumn{2}{|c|}{2009} & \multicolumn{2}{|c|}{2010} & \multicolumn{3}{|c|}{ tent (mg kg") } \\
\hline & Mean & IPCV 1 & Mean & $\mathrm{IPCV}^{1}$ & Mean & IYCV & $\mathrm{mIPCV}^{3}$ & Mean & IPCV & Mean & IPCV & Mean & IYCV & $\mathrm{mIPCV}^{3}$ & Mean I & IPCV & Mean I & IPCV & Mean & IYCV & mIPCV \\
\hline CDP04640 (16) & 21.90 & 0.27 & 15.43 & 0.18 & 18.66 & 0.25 & \begin{tabular}{|l|}
0.22 \\
\end{tabular} & 66.52 & 0.38 & 57.65 & 0.19 & 62.08 & 0.10 & 0.28 & 165.89 & 0.25 & 77.35 & 0.20 & 121.62 & 0.51 & 0.22 \\
\hline CDP00623(16) & 21.30 & 0.16 & 24.21 & 0.48 & 22.75 & 0.09 & 0.32 & 53.22 & 0.27 & 125.02 & 0.20 & 89.12 & 0.57 & 0.24 & 54.59 & 0.77 & 146.55 & 0.20 & 100.57 & 0.65 & 0.49 \\
\hline CDP04486 (16) & 21.51 & 0.12 & 15.97 & 0.49 & 18.74 & 0.21 & 0.30 & 56.44 & 0.26 & 108.75 & 0.66 & 82.60 & 0.45 & 0.46 & 169.72 & 0.29 & 176.92 & 0.64 & 173.32 & 0.03 & 0.47 \\
\hline CDP04829 (16) & 17.23 & 0.06 & 14.30 & 0.28 & 15.76 & 0.13 & 0.17 & 92.51 & 0.03 & 90.92 & 0.29 & 91.71 & 0.01 & 0.16 & 98.66 & 0.15 & 84.11 & 0.36 & 91.38 & 0.11 & 0.25 \\
\hline CDP09978(16) & 19.40 & 0.14 & 24.34 & 0.29 & 21.87 & 0.16 & 0.21 & 42.12 & 0.17 & 107.62 & 0.27 & 74.87 & 0.62 & 0.22 & 156.94 & 0.14 & 133.20 & 0.12 & 145.07 & 0.12 & 0.13 \\
\hline CDP08151 (16) & 18.18 & 0.10 & 13.67 & 0.15 & 15.93 & 0.20 & 0.13 & 70.62 & 0.60 & 75.14 & 0.20 & 72.88 & 0.04 & 0.40 & 142.38 & 0.43 & 123.70 & 0.30 & 133.04 & 0.10 & 0.37 \\
\hline CDP02310(16) & 20.72 & 0.10 & 16.30 & 0.18 & 18.51 & 0.17 & 0.14 & 77.74 & 0.43 & 73.25 & 0.13 & 75.50 & 0.04 & 0.28 & 65.94 & 1.06 & 153.72 & 0.40 & 109.83 & 0.57 & 0.73 \\
\hline CDP00450 (16) & 20.22 & 0.08 & 22.70 & 0.30 & 21.46 & 0.08 & 0.19 & 94.86 & 0.73 & 123.98 & 0.27 & 109.42 & 0.19 & 0.50 & 157.17 & 0.36 & 180.61 & 0.29 & 168.89 & 0.10 & 0.32 \\
\hline CDP07489 (16) & 19.32 & 0.05 & 14.30 & 0.17 & 16.81 & 0.21 & 0.11 & 52.80 & 0.02 & 79.23 & 0.21 & 66.01 & 0.28 & 0.11 & 125.61 & 0.07 & 110.43 & 0.25 & 118.02 & 0.09 & 0.16 \\
\hline CDP00960 (16) & 27.39 & 0.05 & 15.09 & 0.21 & 21.24 & 0.41 & 0.13 & 92.02 & 0.07 & 77.78 & 0.22 & 84.90 & 0.12 & 0.15 & 113.52 & 0.12 & 84.36 & 0.15 & 98.94 & 0.21 & 0.14 \\
\hline CDPO4423(16) & 19.60 & 0.17 & 21.39 & 0.28 & 20.49 & 0.06 & 0.22 & 61.12 & 0.63 & 92.28 & 0.28 & 76.70 & 0.29 & 0.46 & 201.84 & 0.38 & 92.08 & 0.47 & 146.96 & 0.53 & 0.42 \\
\hline CDPO4372 (16) & 19.54 & 0.20 & 17.91 & 0.52 & 18.73 & 0.06 & 0.36 & 68.64 & 0.56 & 75.73 & \begin{tabular}{|l|}
0.47 \\
\end{tabular} & 72.19 & 0.07 & 0.52 & 244.22 & 0.41 & 120.16 & 0.25 & 182.19 & 0.48 & 0.33 \\
\hline CDP02109 (16) & 21.94 & 0.19 & 11.88 & 0.28 & 16.91 & 0.42 & 0.23 & 74.05 & 0.36 & 57.25 & 0.24 & 65.65 & 0.18 & 0.30 & 80.11 & 1.21 & 114.81 & 0.52 & 97.46 & 0.25 & 0.86 \\
\hline CDP05333 (16) & 18.21 & 0.14 & 9.74 & 0.06 & 13.98 & 0.43 & 0.10 & 94.66 & 0.40 & 80.80 & 0.27 & 87.73 & 0.11 & 0.33 & 132.22 & 0.15 & 256.67 & 0.92 & 194.45 & 0.45 & 0.54 \\
\hline CDP05691 (16) & 19.54 & 0.08 & 15.18 & 0.33 & 17.36 & 0.18 & 0.20 & 52.14 & 0.29 & 92.15 & 0.40 & 72.15 & 0.39 & 0.35 & 206.35 & 0.14 & 87.74 & 0.06 & 147.05 & 0.57 & 0.10 \\
\hline CDP00142 (16) & 23.87 & 0.29 & 13.88 & 0.13 & 18.88 & 0.37 & 0.21 & 70.56 & 0.72 & 66.98 & 0.15 & 68.77 & 0.04 & 0.44 & 212.93 & 0.29 & 403.35 & 1.09 & 308.14 & 0.44 & 0.69 \\
\hline CDP05729 (16) & 30.26 & 0.39 & 13.28 & 0.13 & 21.77 & 0.55 & 0.26 & 147.80 & 0.65 & 74.70 & 0.42 & 111.25 & 0.46 & 0.53 & 121.63 & 0.77 & 148.57 & 0.48 & 135.10 & 0.14 & 0.62 \\
\hline CDP01649(16) & 20.03 & 0.20 & 12.21 & 0.18 & 16.12 & 0.34 & 0.19 & 93.78 & 0.99 & 76.35 & 0.27 & 85.06 & 0.14 & 0.63 & 73.92 & 0.70 & 201.71 & 0.42 & 137.82 & 0.66 & 0.56 \\
\hline CDP01949(16) & 23.69 & 0.17 & 14.87 & 0.16 & 19.28 & 0.32 & 0.16 & 68.54 & 0.18 & 80.67 & 0.08 & 74.60 & 0.11 & 0.13 & 148.15 & 0.36 & 154.10 & 0.70 & 151.13 & 0.03 & 0.53 \\
\hline CDP08595 (16) & 22.05 & 0.09 & 12.79 & 0.30 & 17.42 & 0.38 & 0.19 & 104.62 & 0.27 & 76.20 & \begin{tabular}{|l|}
0.45 \\
\end{tabular} & 90.41 & 0.22 & 0.36 & 111.65 & 0.56 & 132.92 & 0.51 & 122.29 & 0.12 & 0.53 \\
\hline CDP02589 (16) & 20.40 & 0.19 & 11.92 & 0.13 & 16.16 & 0.37 & 0.16 & 59.79 & 0.58 & 86.04 & 0.18 & 72.92 & 0.25 & 0.38 & 173.45 & 0.39 & 156.31 & 0.09 & 164.88 & 0.07 & 0.24 \\
\hline CDP04915(16) & 16.27 & 0.08 & 9.37 & 0.23 & 12.82 & 0.38 & 0.15 & 29.74 & 0.04 & 42.58 & 0.31 & 36.16 & 0.25 & 0.18 & 101.37 & 0.12 & 128.02 & 0.44 & 114.69 & 0.16 & 0.28 \\
\hline CDP02182 (16) & 22.93 & 0.31 & 12.75 & 0.29 & 17.84 & 0.40 & 0.30 & 115.61 & 0.88 & 68.77 & 0.27 & 92.19 & 0.36 & 0.57 & 152.45 & 0.27 & 150.63 & 0.45 & 151.54 & 0.01 & 0.36 \\
\hline CDP04052 (16) & 24.36 & 0.14 & 20.35 & 0.40 & 22.36 & 0.13 & 0.27 & 69.21 & 0.37 & 65.13 & 0.45 & 67.17 & 0.04 & 0.41 & 54.89 & 1.02 & 169.21 & 0.50 & 112.05 & 0.72 & 0.76 \\
\hline CDP06753(16) & 21.09 & 0.10 & 12.88 & 0.23 & 16.99 & 0.34 & 0.16 & 63.16 & 0.30 & 54.00 & 0.26 & 58.58 & 0.11 & 0.28 & 134.36 & 0.49 & 89.76 & 0.19 & 112.06 & 0.28 & 0.34 \\
\hline CDP01197 (16) & 28.85 & 0.02 & 14.21 & 0.15 & 21.53 & 0.48 & 0.09 & 112.81 & 0.42 & 84.00 & 0.26 & 98.40 & 0.21 & 0.34 & \begin{tabular}{l|l|}
92.67 \\
\end{tabular} & 0.11 & 140.51 & 0.50 & 116.59 & 0.29 & 0.31 \\
\hline CDP01646 (16) & 28.49 & 0.19 & 17.13 & 0.35 & 22.81 & 0.35 & 0.27 & 74.26 & 0.50 & 65.89 & 0.34 & 70.08 & 0.08 & 0.42 & 14.04 & 1.25 & 86.49 & 0.64 & 50.27 & 1.02 & 0.95 \\
\hline CDP05266 (16) & 26.79 & 0.00 & 13.50 & 0.23 & 20.14 & 0.47 & 0.12 & 108.42 & 0.18 & 62.99 & \begin{tabular}{|l|}
0.07 \\
\end{tabular} & 85.70 & 0.37 & 0.13 & 117.14 & 0.23 & 142.22 & 0.23 & 129.68 & 0.14 & 0.23 \\
\hline CDP03596 (16) & 27.30 & 0.20 & 15.33 & 0.44 & 21.31 & 0.40 & 0.32 & 85.12 & 0.39 & 72.82 & 0.48 & 78.97 & 0.11 & 0.43 & 62.08 & 1.20 & 104.72 & 0.44 & 83.40 & 0.36 & 0.82 \\
\hline CDP07231 (16) & 16.93 & 0.03 & 11.53 & 0.27 & 14.23 & 0.27 & 0.15 & 27.22 & 0.25 & 58.68 & 0.29 & 42.95 & 0.52 & 0.27 & 90.90 & 1.15 & 162.89 & 0.22 & 126.9 & 0.40 & 0.69 \\
\hline 'Razymo RZ' & 21.89 & 0.31 & 11.41 & 0.20 & 16.65 & 0.45 & 0.26 & 70.26 & 0.42 & 48.54 & 0.25 & 59.40 & 0.26 & 0.33 & 76.31 & 0.93 & \begin{tabular}{|l|}
100.82 \\
\end{tabular} & 0.45 & 88.57 & 0.20 & 0.69 \\
\hline 'Gransol RZ' & 20.41 & 0.15 & 24.80 & 0.54 & 22.61 & 0.14 & 0.35 & 58.86 & 0.36 & 103.36 & \begin{tabular}{|l|}
0.45 \\
\end{tabular} & 81.11 & 0.39 & 0.41 & 115.52 & 0.54 & 146.83 & 0.26 & 131.18 & 0.17 & 0.40 \\
\hline \begin{tabular}{|l} 
'Piccota RZ' \\
\end{tabular} & 26.95 & 0.09 & 25.82 & 0.23 & 26.39 & 0.03 & 0.16 & 53.23 & 0.17 & 55.66 & 0.08 & 54.45 & 0.03 & 0.13 & 183.08 & 1.07 & \begin{tabular}{|l|}
327.47 \\
\end{tabular} & 0.71 & 255.28 & 0.40 & 0.89 \\
\hline 'Mariscal RZ' & \begin{tabular}{|l|l|}
19.74 \\
\end{tabular} & 0.09 & 12.67 & 0.13 & 16.20 & 0.31 & 0.11 & $\mid 117.76$ & 0.34 & 73.20 & \begin{tabular}{|c|}
0.23 \\
\end{tabular} & 95.48 & 0.33 & 0.29 & 106.60 & 1.13 & 57.99 & 0.31 & \begin{tabular}{|l|}
82.30 \\
\end{tabular} & 0.42 & 0.72 \\
\hline
\end{tabular}

${ }^{1} I P C V$ :Intra-population coefficient of variation for the year. ${ }^{2} I Y C V$ Intra-year coefficient of variation (using the mean contents of 2009 and 2010 ). ${ }^{3} \mathrm{mIPCV}: \mathrm{Mean} I P C V$. 
Table 4. Varietal mean contents and levels of variation.

Ascorbic acid $\left(\mathrm{mg} \mathrm{kg}^{-1}\right)$

$\beta$-carotene $\left(\mathrm{mg} \mathrm{kg}^{-1}\right)$

Lycopene $\left(\mathrm{mg} \mathrm{kg}^{-1}\right)$

\begin{tabular}{|c|c|c|c|c|c|c|c|c|c|c|}
\hline VARIETY & 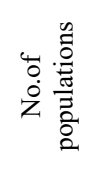 & 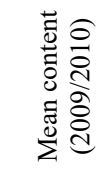 & 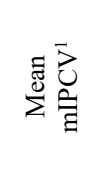 & 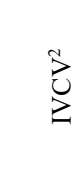 & 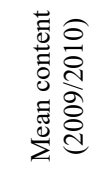 & 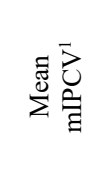 & $\stackrel{己}{Z}^{\tilde{z}}$ & 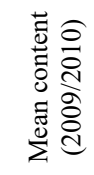 & 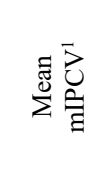 & $\sum_{z}^{3}$ \\
\hline 'Amarillo' & 1 & 149.54 & 0.12 & 0.00 & 10.73 & 0.09 & 0.00 & 12.40 & 0.14 & 0.00 \\
\hline 'Centenares' & 1 & 221.27 & 0.42 & 0.00 & 19.81 & 0.11 & 0.00 & 100.76 & 0.28 & 0.00 \\
\hline 'Cuarenteno' & 6 & 161.93 & 0.34 & 0.36 & 16.58 & 0.13 & 0.09 & 65.90 & 0.30 & 0.21 \\
\hline 'De golgar' & 10 & 184.84 & 0.61 & 0.48 & 23.59 & 0.22 & 0.25 & 48.31 & 0.41 & 0.43 \\
\hline 'De la pera' & 4 & 122.85 & 0.36 & 0.28 & 17.68 & 0.16 & 0.19 & 74.28 & 0.35 & 0.33 \\
\hline 'De pera' & 3 & 136.99 & 0.27 & 0.22 & 13.84 & 0.18 & 0.12 & 99.31 & 0.28 & 0.22 \\
\hline 'Elchero' & 1 & 181.24 & 0.33 & 0.00 & 18.67 & 0.20 & 0.00 & 67.31 & 0.38 & 0.00 \\
\hline 'Flor de baladre' & 2 & 156.12 & 0.29 & 0.48 & 19.26 & 0.18 & 0.15 & 68.24 & 0.36 & 0.01 \\
\hline 'Gordo rojo' & 4 & 126.04 & 0.57 & 0.30 & 17.07 & 0.18 & 0.13 & 77.16 & 0.30 & 0.34 \\
\hline 'Muchamiel' & 28 & 130.66 & 0.37 & 0.36 & 17.31 & 0.16 & 0.17 & 52.07 & 0.32 & 0.30 \\
\hline 'Negre' & 1 & 194.05 & 0.30 & 0.00 & 14.62 & 0.15 & 0.00 & 47.97 & 0.22 & 0.00 \\
\hline 'Pimiento' & 8 & 126.83 & 0.54 & 0.37 & 15.53 & 0.19 & 0.10 & 92.16 & 0.38 & 0.26 \\
\hline 'Redondo rojo' & 2 & 119.84 & 0.49 & 0.12 & 25.09 & 0.22 & 0.38 & 82.47 & 0.36 & 0.23 \\
\hline 'Rosa' & 12 & 120.10 & 0.56 & 0.51 & 14.82 & 0.13 & 0.12 & 69.55 & 0.39 & 0.53 \\
\hline 'Tres cantos' & 1 & 51.33 & 0.38 & 0.00 & 15.92 & 0.14 & 0.00 & 51.33 & 0.38 & 0.00 \\
\hline 'Valenciano' & 42 & 73.83 & 0.33 & 0.29 & 18.13 & 0.20 & 0.21 & 73.83 & 0.33 & 0.29 \\
\hline
\end{tabular}

${ }^{1}$ Mean mIPCV: Mean inter-population coefficient of variation for both years. ${ }^{2} \mathrm{IVCV}$ : Intra-varietal coefficient of variation. 
Fig. 1. Climatic conditions of cultivation, including maximum temperature, minimum temperature and photosynthetically active radiation. Arrows indicate the date of start and end of harvest (continuous: 2009; dotted: 2010).

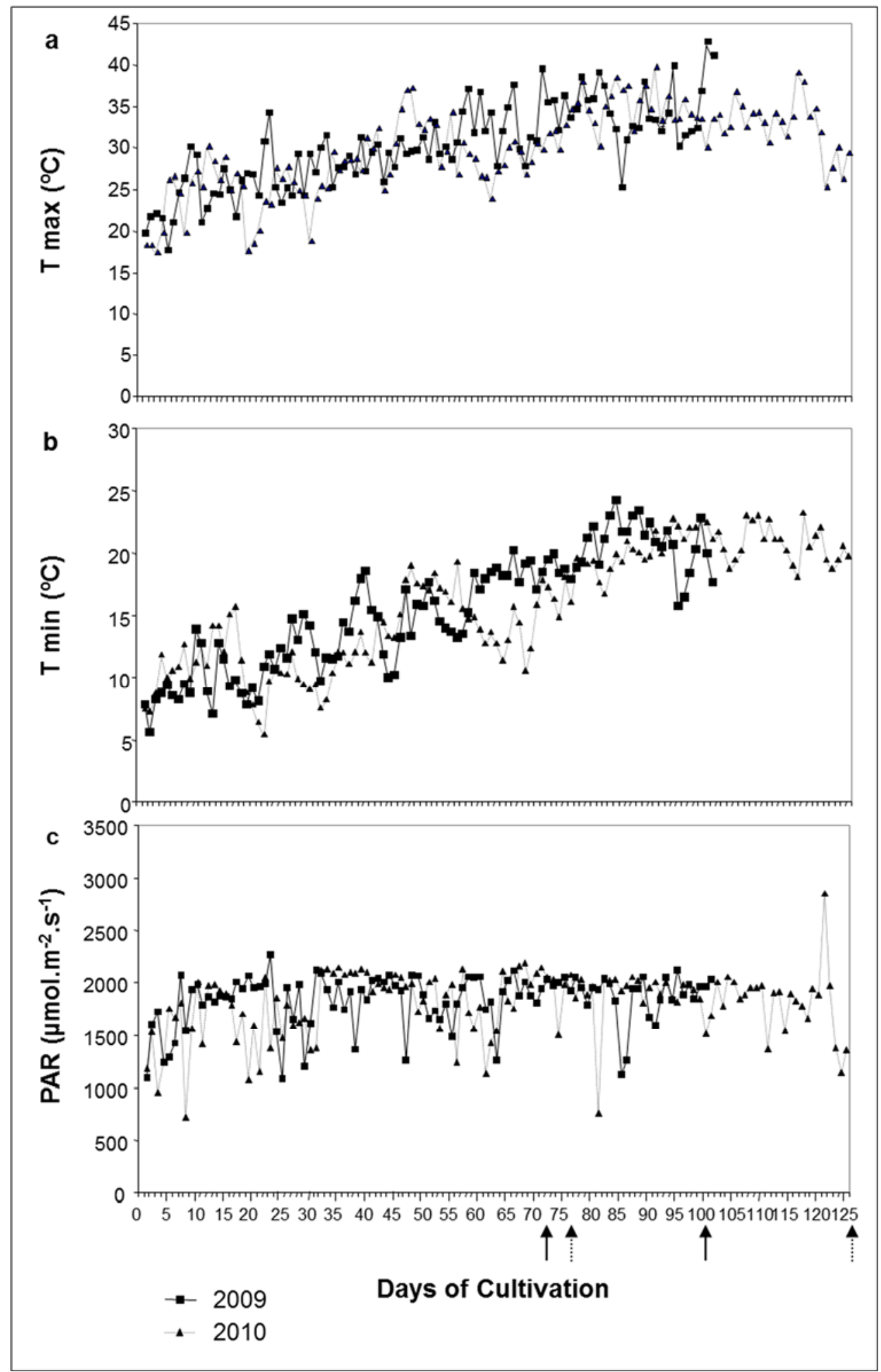

51. 